INTERDISCIPLINARIA ARCHAEOLOGICA NATURAL SCIENCES IN ARCHAEOLOGY

\title{
An Investigation of Dental Health in the Migration Period: A Case Study from Prague-Zličín, Czech Republic
}

\author{
Ivana Jarošováa ${ }^{*}$ \\ aLabrys, o. p. s., Hloubètínská 16/11, 19800 Praha 9, Czech Republic
}

\section{ARTICLE INFO}

\section{Article history:}

Received: $11^{\text {th }}$ December 2015

Accepted: $1^{\text {st }}$ August 2016

\section{Key words:}

Migration period

dental caries

pre-mortem tooth loss

dental enamel hypoplasia

dental wear

diet

\begin{abstract}
A B S TRACT
In this study, 97 individuals from Prague-Zličín, in central Bohemia, Czech Republic, were scored for basic dental features, including dental caries, prevalence of dental enamel hypoplasia (DEH), and dental wear patterns, in order to discover basic characteristics of their diet, and the extent of nonspecific stressors (i.e. indicators of metabolic and nutritional disruptions) during the Migration Period ( $5^{\text {th }}$ century AD). The sample is comprised of 18 subadults $(0-14$ year-old) and 79 adult individuals over 15 years, with a total number of 1129 permanent and 111 deciduous teeth.

Values of caries intensity were 21.0 and its frequency 59.5. Higher values of caries intensity were found in males (24.0) than in the female population (21.3). The most frequent type of dental caries was found in the mesial and distal facets of the cemento-enamel junction and smooth surfaces of the crown $(64.1 \%)$, which may be connected with deteriorated oral hygiene in this series. The $9.8 \%$ of dental caries located on the occlusal surface of the crown can be interpreted, together with the proven low dental wear, as the existence of a softer diet during this Migration period than in the former Neolithic period.

DEH was present at a high frequency $(32.2 \%$ of all examined individuals), but nearly all of these records of past stressors in childhood have only short-term acute forms in the way of lines or grooves. Only one single case provided evidence for a chronic form of DEH. The timing of linear enamel hypoplasia (LEH) studied in 13 individuals provides an assessment of the occurrence and frequency of age when LEH formed. Overall anthropological analysis suggests a relative high number of indicators of environmental stressors related to the prevalence of dental caries, pre-mortem tooth loss and the prevalence scores of DEH.
\end{abstract}

\section{Introduction}

The study of a population's state of health and overall fitness are also items of interest to skeletal biologists. This paper is a study made of the main dental aspects of a population sample from the Migration period recovered from PragueZličín in Central Bohemia. The aim was to capture the changes inscribed in the dentition of this past population, by which a partial reconstruction of the living conditions of that time could be made, along with an assessment of the dental health of studied individuals. To achieve this aim, the

*Corresponding author. E-mail: ivanajar@gmail.com study investigated three main signs of dental health or dental diseases, i.e. caries, dental wear and enamel hypoplasia (Aufderheide, Rodríguez-Martín 1998), through which it is possible to reconstruct not only some aspects of the food consumed, but also the state of health of the past population by comparing these data with other chronologically and geographically different series from the Czech Republic.

Dental caries (caries dentis) is an irreversible microbial disease of the calcified tissues of the teeth, characterized by demineralization of the inorganic portion and destruction of the organic substance of the tooth, which often leads to cavitation (Sivapathasundharam, Raghu 2012). An advanced caries can lead to loss in vitality of dental pulp and finally to the loss of a tooth, or eventually to other pathological 
processes (Kilian et al. 1999). The emergence of caries depends on the susceptibility of dental tissues (constitutional and genetic factors, sex, and age), the composition of oral microflora (dental plaque microorganisms are cariogenic), nutrition factors and time, i.e. the frequency and duration of interaction, which is also closely related with oral hygiene (Kilian et al. 1999; Wotke 2001). The dependence of dental cariosity on the food composition of historical populations has been a topic treated by many authors (e.g. Lillie 1996; Saunders et al. 1997; Lingström, Borrman 1999). Palaeolithic and Mesolithic hunter-gatherers show the lowest caries rate; in Neolithic populations that began to settle down and switch to an agricultural way of life, caries rates gradually increased. This was connected with a transition to other types of food, which, over the course of centuries, and in contrast to preceding periods, contained more sugar; this food was also more elaborately prepared and relieved of undesirable ingredients such that the roughage content in food was gradually reduced (Caselitz 1998, 205). Dental wear is the loss of the dental surface due to external mechanical forces, above all in connection with food. The degree of dental wear depends not only on the coarseness of particles, but also on the condition of dental surfaces, because particles stick easier to a roughened surface than to a smooth one (Mair et al. 1996; Mair 1999). Further, there is also a peculiar form of wear that is concentrated to one single tooth or a group of teeth. This type of wear is mostly caused by objects coming in contact with teeth, and these processes are designated collectively as influences due to an individual's profession.

The deterioration of environmental factors can result in a disturbed physiological balance - not only in individuals, but also in the population as a whole. Once a person exposed to a non-specific stress exceeds their resistance threshold, then their physiological balance can be disturbed, sometimes resulting in a complete cascade of changes. This turnover leads to the emergence of non-specific stress markers (Harris lines, dental enamel hypoplasia, cribra orbitalia, etc.), which can be subsequently observed on skeletal remains. The impact of stress on a whole population is reflected not only in the fitness and physical efficiency (reduced work effort) of the decreased, but also in a diminished reproductive capacity (increased abortion rate and reduced viability of newborns). All these factors are reflected in the disturbed socio-economic balance of the entire population (Goodman, Armelagos 1989; Larsen 1997). Dental enamel hypoplasia examined in individuals thus offers valuable information on the state of health and overall fitness of a population, and helps towards the retrospective reconstruction of a population's behaviour and adaptation to the environment it occupies.

\section{Material}

Certain aspects of the archaeological burial ground from the Migration period ( $5^{\text {th }}$ century AD) have already been published (Vávra et al. 2008; Vávra et al. 2012; Jiřík et al. 2015), but a comprehensive anthropological evaluation is first published in detail in this issue, even though some partial studies concerning the evaluation of demographic distribution and metrical characteristics were already published (Víšková et al. 2012; Horáková et al. 2014; Horáková, Jarošová 2015).

Out of the total number of 180 detected individuals, 97 $(53.9 \%)$ could be studied for their dentition or jaws. The state of dentition state could thus be evaluated in 18 subadults (0-14 years) and 79 adults (15+ years) (Table 9), who are further subdivided into sex and age categories. Of the individuals from the remaining 83 burials $(46.1 \%)$ that had to be excluded from the dental health analysis: 9 individuals were excluded due to their jaws with teeth being found in poor condition or preserved only fragmentarily without the possibility to assess at least tooth type (grave no. 11, 21, 28, $58,130,139,140,166,177)$; and the remaining 74 detected graves were excluded because of the absence of dental remains in the skeletal parts, which were either completely absent or preserved only fragmentarily without any tooth.

As comparative samples the following were used: two Neolithic series from Moravia, consisting of 73 individuals belonging to the Linear Pottery Culture (LBK 5700-4900 $\mathrm{BC}$ ), and 21 to the Lengyel culture, well known in Moravia as the Moravian Painted Pottery Culture (LgK 4700-4000 BC) (Jarošová, Dočkalová 2008); and an Early Middle Age population from Dolní Věstonice - Na Pískách that included 893 individuals, localized in South Moravia and dated back to the $9^{\text {th }}-11^{\text {th }}$ century AD (Jarošová 2007; Hrnčírová, Jarošová 2007; Jarošová et al. 2012). All three comparative series are localized in the Czech Republic about 250 kilometers from the Prague-Zličín sample and were examined by the same author using the unified list of methods (see below).

\section{Methods}

The analyzed occurrence of caries and hypoplasia included both individuals with deciduous teeth and those with permanent teeth. The analysis of dental wear only included adult individuals aged over 20 with permanent dentition. For individuals from the Prague-Zličín series to be selected, the presence of at least one intact tooth of whatever type was demanded both in the maxillas and the mandible, no matter if on the right or left side.

The state of preservation of teeth and jaws was assessed using two indices - the comparative alveolar index (CAI) and the comparative dental index (CDI). CAI is characterized as a relation between the number of preserved alveoli and the number of all burials multiplied by $32[\mathrm{CAI}=\mathrm{A} /(\mathrm{n} \times 32)]$, and CDI is described as a relation between the number of preserved erupted teeth, the number of teeth lost intravitam (i.e. ante-mortem) and the number of all burials multiplied by $32[\mathrm{CDI}=(\mathrm{Z}+\mathrm{E}) /(\mathrm{n} \times 32)]$ (Hanáková, Stloukal 1966).

The presence or absence of caries (C) was evaluated macroscopically. Upon the recommendation of Buikstra and Ubelaker (1994), the type of caries was evaluated macroscopically in both deciduous and permanent teeth, 
according to the numerical codes adapted by Moore and Corbett (1971): 1 = occlusal surface caries; 2 = smooth surface caries - interproximal (i.e. approximal) surfaces (mesial and distal); $3=$ smooth surface caries (buccal/ labial and lingual/vestibular surfaces); 4 = cervical caries interproximal (i.e. approximal) surfaces (mesial and distal); $5=$ cervical caries (except interproximal surfaces); $6=$ root caries (below CEJ).

During the assessment of dental cariosity, consideration should be given to particular age categories, since cariosity increases with age. Thus subadults $(0-14$ yrs $)$ with deciduous and mixed dentition were separated from juvenile (15-19 yrs) and adult individuals with permanent teeth, and in the final evaluation the group of subadults was treated separately. In the group of adults there were also juveniles included and this group was further divided into four subcategories: 15-19 yrs, 20-35 yrs, 35-50 yrs and over 50 yrs. Our understanding of the term "adult" is based on a consideration of an adult individual primarily in terms of social status, not biological status. This processing involved the data concerning healthy teeth $(\mathrm{T})$, carious teeth $(\mathrm{C})$, teeth lost intravitam (i.e. premortem) (E) and post-mortem (P). If a pre-mortem tooth loss occurred (E), such teeth were evaluated as carious (C), even in the case that this loss possibly occurred due to other, as yet indeterminable, reasons - loss caused by strong wear, abscess, periodontal disease or trauma (Andrik, Müncnerová 1961). The teeth lost post-mortem (P) were not included in the general evaluation of caries intensity and frequency. This general evaluation was performed following the method developed by Stloukal (Stloukal 1963). The abbreviations used $(\mathrm{Z}, \mathrm{A}, \mathrm{E}, \mathrm{C}, \% \mathrm{C}, \mathrm{n}, \mathrm{nC}, \% \mathrm{nC}, \mathrm{nE}, \% \mathrm{nE}, \mathrm{nCE}, \% \mathrm{nCE}$, I-CE, F-CE - for explanation see Table 1) were also adopted from this method elaborated by Stloukal (1963) (for a detailed description and relationships among the listed abbreviated terms, see Stloukal 1963 or Jarošová, Dočkalová 2008).

The attrition rates for incisors, canines and premolars were recorded according to an eight-point scale based on the amount of exposed dentine (Smith 1984). Since the Smith system shows only a poor level of discrimination when attrition rates are moderate to low, Buikstra and Ubelaker (1994) prefer the standards developed by Scott (1979) for molars. In the Scott system, each molar occlusal surface is divided into quadrants, and the amount of observable enamel is scored on a scale from 4 to 40 . If any of the quadrants was not observable, then such a tooth was not recorded.

Dental enamel hypoplasia (DEH) can be defined, regarding its emergence, as an evolutionary defect of the hard dental tissues that are a reflection of various non-specific stress indicators in recent, historical and palaeoanthropological populations, and thus DEH offers a unique record of the stress suffered in childhood, which can be also subsequently observed in the dentition of adult individuals. These enamel defects can be interpreted as displays of nutritional deficiencies and infectious diseases (El-Najjar et al. 1978; Goodman 1998; Hodges, Wilkinson 1990; Lukacs 1992; Goodman 1993; Malville 1997; Wright 1997). DEH was examined on three tooth types (I1, I2, C). This selection followed procedural considerations of, above all, Goodman and Armelagos (1985), who have been quoted that, from the morphogenetic point of view, chiefly the upper central incisors and mandibular canines are the most sensitive to the formation of hypoplasia.

Following types of hypoplasia were defined: 1. Teeth with a degree of wear higher than $1 / 3$ of the overall crown

Table 1. Caries intensity (I-CE) in adults (15+ yrs) of analysed sample from Prague-Zličín according to sex [C, number of carious teeth; \%C, caries incidence (the percentage of decayed teeth from total number of preserved teeth); E, number of teeth lost pre-mortem; \%E, the percentage of pre-mortem losses; A, number of preserved dental alveoli]. Caries frequency (F-CE) in adults (15+ yrs) of analysed sample from Prague-Zličín according to sex [nC, individuals with at least one caries; $\mathrm{nE}$, individuals with at least one pre-mortem loss; $\mathrm{nCE}$, individuals with both caries and pre-mortem losses].

\begin{tabular}{lcccc}
\hline \multicolumn{1}{c}{ Individuals (15+ yrs) } & Males & Females & ? & All individuals \\
\hline Number of examined teeth (n) & 295 & 479 & 153 & 927 \\
$\mathrm{C}$ & 19 & 54 & 16 & 89 \\
$\% \mathrm{C}$ & 6.4 & 11.3 & 10.5 & 9.6 \\
$\mathrm{E}$ & 71 & 60 & 0 & 131 \\
$\mathrm{~A}$ & 404 & 596 & 153 & 1153 \\
$\% \mathrm{E}$ & 17.6 & 10.1 & 0 & 11.4 \\
$\mathrm{I}-\mathrm{CE}$ & 24.0 & 21.3 & 10.5 & 21.0 \\
Number of examined individuals $(\mathrm{N})$ & 22 & 30 & 27 & 79 \\
$\mathrm{nE}$ & 5 & 2 & 0 & 7 \\
\%nE & 22.7 & 6.7 & 0 & 8.9 \\
$\mathrm{nC}$ & 5 & 8 & 9 & 22 \\
$\% \mathrm{nC}$ & 22.7 & 26.7 & 33.3 & 27.8 \\
nCE & 6 & 12 & 0 & 18 \\
\%nCE & 27.3 & 40.0 & 0 & 22.8 \\
intact & 6 & 8 & 18 & 32 \\
$\%$ intact & 27.3 & 26.7 & 66.7 & 40.5 \\
F-CE & 72.7 & 73.3 & 33.3 & 59.5 \\
\hline
\end{tabular}


height; teeth with the presence of tartar and teeth with postmortal enamel defects were excluded from the analysis. 2. Afterwards, the presence or absence of dental enamel hypoplasia was macroscopically examined on the labial surface of each tooth. 3. In the case of dental enamel hypoplasia being detected, the type of hypoplastic defect was determined according to the DDE index: lines (FDI type 4: L-lines, G-grooves); pits (FDI type 3: Ps-pits, Pl-pit line); and chronic enamel hypoplasia (i.e. ,pit patches“ and ,continuous chronic enamel hypoplasia“) (Santos, Coimbra 1999; Goodman et al. 1992; Goodman, Rose 1990; Ensor, Irish 1995; Sarnat, Schour 1941; Corruccini et al. 1985; Littleton 2005; Obertová 2005; Jarošová 2007; Jarošová et al. 2012, etc.). Lines and pits are classified in this paper as acute DEH (A DEH). Timing of linear hypoplasia on anterior teeth with regard to tooth growth was assessed after Reid, Dean (2000).

\section{Results}

\subsection{State of preservation of teeth and jaws}

The state of preservation of alveoli and teeth in individuals from the Prague-Zličín population was characterised by the comparative alveolar index CAI and comparative dental index CDI. In the studied series less than half the teeth (41.9\%) and alveoli (45.61\%) were available for analysis; unfortunately this only allows us to make approximations in the results presented below and reduces the confidence in data reliability (see Table 9). Despite this extremely low number, other studied samples have also shown similar results (e.g. Early Medieval sample from Dolní Věstonice - Na Pískách had CDI 40.1\% and CAI 59.7\%), but some of the comparative samples showed even higher values Neolithic samples from Moravia had CDI $60.4 \%$ and CAI 70.5\% (Jarošová 2007; Jarošová, Dočkalová 2008; Jarošová et al. 2012).

\subsection{Carious teeth}

The occurrence of caries was analysed in 18 subadult and 79 adult individuals, with a total of 1,240 teeth, from the Prague-Zličín series in Central Bohemia. The evaluation of cariosity could be thus performed on 97 individuals (Table 1), representing 53.8\% of the available 180 human remains from 176 burials in 173 graves at the burial ground of Prague-Zličín.

During this epidemiological study based on direct inspection, all teeth of deciduous and permanent dentition were examined, both maxillar and mandibular. The general evaluation of the occurrence of caries in the dentition of adults included the testing of two mutually-independent criteria, i.e. sex and age (i.e. subadults versus adults), and it was carried out based on the following analytic scheme: caries intensity (I-CE), caries frequency (F-CE) and type of dental caries.

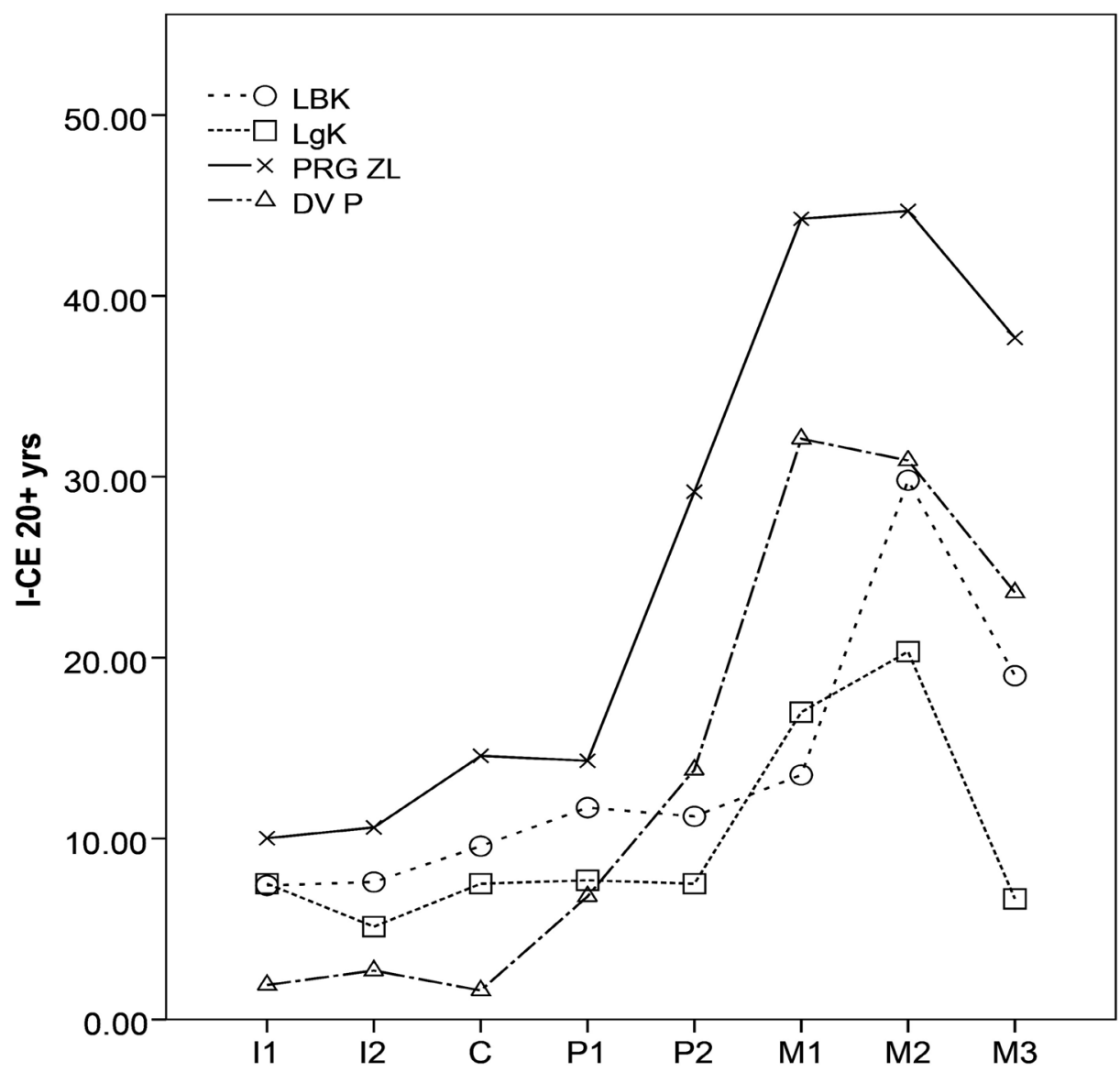

Figure 1. Caries intensity in adults (20+ yrs) according to tooth types of the analysed groups from: Neolithic settlements (LBK, $\mathrm{LgK}$ ); the Migration period (Prague-Zličín; PRG ZL); and an Early Medieval sample from Dolní Věstonice - Na Pískách (DV P). For data sources, see Jarošová 2007 and Jarošová, Dočkalová 2008. For the Prague Zličín sample: $\mathrm{I} 1=10.0 ; \mathrm{I} 2=10.6 ; \mathrm{C}=14.6 ; \mathrm{P} 1=14.3$; $\mathrm{P} 2=29.2 ; \mathrm{M} 1=44.3 ; \mathrm{M} 2=44.7 ; \mathrm{M} 3=37.7$. 
4.2.1 Caries intensity (I-CE) and Caries frequency (F-CE) In the studied Prague-Zličín sample examined, 131 of a total of 1153 preserved alveoli (A) were detected as intravital losses, and 89 of a total of 927 permanent teeth were carious in individuals above 15 years old. The final I-CE is herewith 21.0. The highest caries rate $(\% \mathrm{C})$ was detected in females, whereas the highest ratio of ante-mortem losses $(\% \mathrm{E})$ could be detected in males. It can be stated that the I-CE of males is 24.0 and of females 21.3 (Table 1). Despite the high caries intensity in males and females, for the ambiguous individuals in the Prague-Zličín sample it was impossible to score antemortem loss as no remains of their jaws were present for study. This is the main cause for such a low caries intensity value ( $\mathrm{I}-\mathrm{CE}=10.5)$, rather than an indication of the good state of their dentition. The comparative Neolithic sample $(20+$ years) showed a very low caries intensity of $10.2(\% \mathrm{C}=3.1$; $\% \mathrm{E}=7.1$, and the Early Medieval sample at Dolní Věstonice - Na Pískách (20+ years) also showed lower values of 15.3 $(\% \mathrm{C}=6.9 ; \% \mathrm{E}=8.4)$ (Jarošová, Dočkalová 2008; Jarošová 2007; Jarošová et al. 2012) than the examined series from Prague-Zličín. With regard to tooth types, the highest I-CE values were found in all tooth types of individuals from the Migration period (Figure 1). The results from the comparative samples show that either the dental health status of individuals from Prague-Zličín was quite poor or the composition of their diet was rich in saccharides, i.e. the sugars that are the main cause of increased dental caries.

In a complete evaluation of caries intensity with regard to age categories within the investigated period, we should undoubtedly prove an increase of values with increasing age. Unfortunately, we are lacking sufficient data to proportionally represent individuals by particular age category. The data quoted are only fragmentary and one should regard the resulting I-CE values in many cases to be unrepresentative, as, for example, in the case of males between 20 and 35 years. The population of Prague-Zličín males and females coincide with their zero I-CE values in the 15-20 year age category, which means completely healthy dentition for the individuals involved. The highest $\mathrm{I}-\mathrm{CE}$ value of 33.0 was found in males over 50 years old $(\% \mathrm{C}=8.0 ; \% \mathrm{E}=25.0)$. The second highest I-CE value was recorded in males between $35-50$ years old $(\% \mathrm{C}=9.3 ; \% \mathrm{E}=19.4)$, while the healthiest teeth were detected in males $15-35$ years old where the sum of caries rate and the ratio of ante-mortem losses only reached $0.0 \%$ (Table 2). This unexpected result was caused more by the lack of available teeth for caries examination in the sample of males 20-35 years old, rather than the extremely healthy status of males in this age range and must be treated with reserve. The female sample provided more reliable data, although the sample of their age categories was also very low (see Table 2).

The caries frequency, i.e. percentage of caries and intravital losses depending on the number of individuals, could be evaluated in 79 adults (15+ years). In the case of some males from Prague-Zličín (burial 18 and 164), only the alveoli stayed preserved, all of their teeth having been lost ante-mortem. Among the individuals of Prague-Zličín studied, more than half were affected by caries or antemortem loss ( $\mathrm{F}-\mathrm{CE}=59.5)$; in both males and females, caries or ante-mortem loss did not occur in only every fourth individual examined (males: $\mathrm{F}-\mathrm{CE}=72.7$; females 73.3 ) (Table 1). Despite of the high caries frequency in males and females, ambiguous individuals in the Prague-Zličín sample had no ante-mortem loss, which resulted in an unexpected F-CE of 33.3. On the other hand, no remains of their jaws were present for study of ante-mortem loss: this was the main cause of such a low caries frequency, rather than the good state of their dentition. In spite of this "gap", we can conclude that in the Migration period more than two thirds of inhabitants were affected by a pathological change in teeth and jaws. For comparison, in the population from Moravian Neolithic settlements $38.8 \%$ of adult individuals ( $20+$ years) were affected by dental caries or ante-mortem loss (Jarošová, Dočkalová 2008). The F-CE of the medieval population from Dolní Věstonice - Na Pískách (20+ years) was 59.6 (Jarošová 2007; Jarošová et al. 2012), which means that the Migration period population showed a higher cariosity than those in the previous periods; even when the youngest category of 15-20-year-old individuals was also included in the final calculation, still the caries occurred in individuals about 1.5 times more often than in the Neolithic populations.

The caries incidence $(\% \mathrm{C})$ at the LBK, LgK, Neolithic settlements, the Neolithic graveyard of Vedrovice (LBK) and the Early Medieval sample from Dolní Věstonice (Jarošová,

Table 2. Caries intensity (I-CE) in adults (15+ yrs) of analysed sample from Prague-Zličín according to age categories [C, number of carious teeth; \%C, caries incidence (percentage of decayed teeth from total number of preserved teeth); E, number of teeth lost pre-mortem; \%E, the percentage of pre-mortem losses; A, number of preserved dental alveoli].

\begin{tabular}{lcccccccc}
\hline \multirow{2}{*}{ Individuals (15+ yrs) } & \multicolumn{4}{c}{ Males } & \multicolumn{4}{c}{ Females } \\
\cline { 2 - 9 } & $\mathbf{1 5 - 1 9}$ & $\mathbf{2 0 - 3 5}$ & $\mathbf{3 5}-\mathbf{5 0}$ & $\mathbf{5 0}+$ & $\mathbf{1 5 - 1 9}$ & $\mathbf{2 0 - 3 5}$ & $\mathbf{3 5}-\mathbf{5 0}$ & $\mathbf{5 0 +}$ \\
\hline Number of examined teeth (n) & 69 & 9 & 129 & 88 & 44 & 68 & 286 & 81 \\
$\mathrm{C}$ & 0 & 0 & 12 & 7 & 1 & 5 & 43 & 5 \\
$\% \mathrm{C}$ & 0.0 & 0.0 & 9.3 & 8.0 & 2.3 & 7.4 & 15.0 & 6.2 \\
$\mathrm{E}$ & 0 & 0 & 36 & 35 & 0 & 13 & 34 & 13 \\
$\mathrm{~A}$ & 69 & 9 & 186 & 140 & 44 & 82 & 365 & 105 \\
$\% \mathrm{E}$ & 0.0 & 0.0 & 19.4 & 25.0 & 0.0 & 15.9 & 9.3 & 12.4 \\
$\mathrm{I}-\mathrm{CE}$ & 0.0 & 0.0 & 28.7 & 33.0 & 2.3 & 23.2 & 24.4 & 18.6 \\
Number of examined individuals (N) & 3 & 2 & 10 & 7 & 2 & 5 & 18 & 5 \\
\hline
\end{tabular}




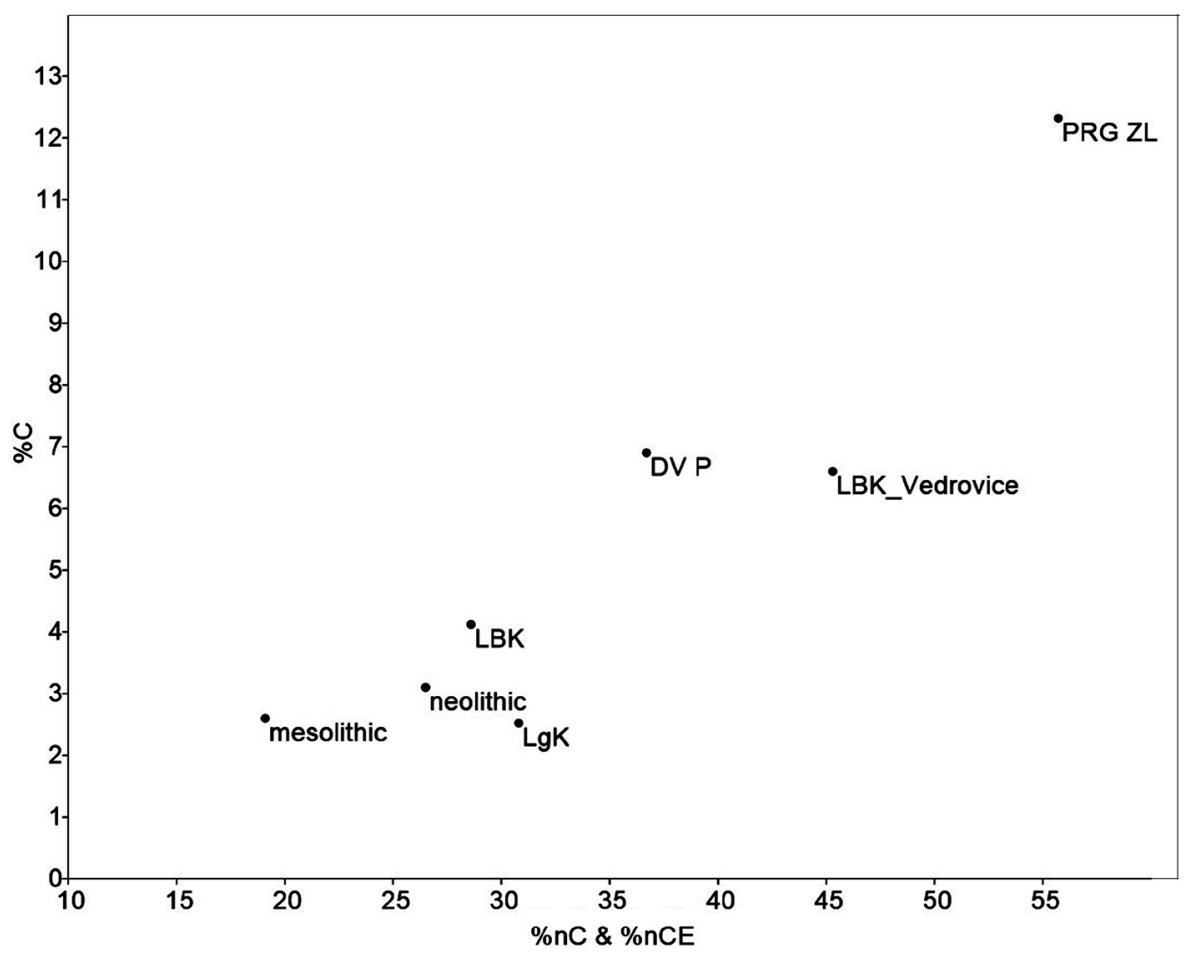

Figure 2. Scatterplot of caries incidence in adults $(20+$ yrs $): \% \mathrm{C}$ against $\% \mathrm{nC}+\% \mathrm{nCE}$ in Mesolithic; Neolithic (LBK, LgK, and all individuals from Neolithic settlements); burial ground Vedrovice dated to Neolithic (LBK); Migration period (PRG ZL) and Early Medieval sample from Dolní Věstonice - Na Pískách (DV P) samples. For data sources, see Frayer 2004; Jarošová 2007 and Jarošová, Dočkalová 2008; for Prague-Zličín sample: $\% \mathrm{C}=12.32$; $\% \mathrm{nC}+\% \mathrm{nCE}=55.71$.

Dočkalová 2008; Jarošová 2007; Jarošová et al. 2012; Frayer 2004) showed lower values in all cases than the sample from Prague-Zličín. The values of settlement populations from the $\mathrm{LBK}$ and $\mathrm{LgK}$ periods approached rather the $\% \mathrm{C}$ of Mesolithic European populations (Frayer 2004), whereas the graveyard of Vedrovice (LBK) has a similar caries incidence as the Early Medieval sample from Dolní Věstonice. The sample from the Migration period has twice a value of $\% \mathrm{C}$. From among the comparative data of selected dated series we display only the $\% \mathrm{nC}$, i.e. the number of affected individuals represented in a sample. Using the "total" $(\mathrm{M}+\mathrm{F}+$ ?) category, $45.3 \%$ at Vedrovice (\%nC: males $=38.1$; females 55.3 ) possessed at least one caries. The ratio of adults with at least one caries in the Mesolithic is 19.1\% (Frayer 2004), but the number of afflicted individuals at the Vedrovice graveyard is more than twice as high. These data cannot be compared to the Czech Neolithic populations (LBK, LgK and Neolithic settlements), because the total number of affected individuals with at least one caries was counted in a different way (i.e. $\% \mathrm{nC}+\% \mathrm{nCE}$ ). These values are thus: LBK 28.6 (males 37.5; females 33.3), $\operatorname{LgK} 30.8$ (males 50.0; females 30.8), and for the entire Neolithic population from settlements 26.5. Compared to Frayer's data, $\% \mathrm{nC}+\% \mathrm{nCE}$ from Czech Neolithic settlements show slightly higher values than in the preceding period, but lower than those from the population of Vedrovice. The sample from Prague-Zličín shows a value of 55.71 for $\% \mathrm{nC}+\% \mathrm{nCE}$ (males 57.9; females 75.0), which is even twice higher than the Vedrovice graveyard. The Early Medieval sample from Dolní Věstonice has a value of 36.7 (males 37.9; females 36.2), which is similar to the Vedrovice sample. To summarise, Prague-Zličín shows the highest caries incidence for the tooth level and also the

Table 3. Dental caries in subadults (0-14 yrs) of analysed sample from Prague-Zličín.

\begin{tabular}{lccc}
\hline & 0-6 yrs & 7-14 yrs & All individuals \\
\hline number of examined children $(\mathrm{N})$ & 11 & 7 & 18 \\
children with caries $(\mathrm{nC})$ & 0 & 0 & 0 \\
\% children with caries $(\% \mathrm{nC})$ & 0 & 0 & 0 \\
number of deciduous teeth & 99 & 12 & 111 \\
number of permanent teeth & 112 & 90 & 202 \\
number of all teeth $(Z)$ & 211 & 102 & 0 \\
caries in deciduous teeth & 0 & 0 & 0 \\
caries in permanent teeth & 0 & 0 & 0 \\
number of all caries $(\mathrm{C})$ & 0 & 0 & 0 \\
$\%$ caries in deciduous teeth $(\% \mathrm{C})$ & 0 & 0 & 0 \\
$\%$ caries in permanent teeth $(\% \mathrm{C})$ & 0 & 0 & 0 \\
\% number of all teeth with caries $(\% \mathrm{C})$ & 0 & 0 & \\
\hline
\end{tabular}


Table 4. Dental caries type and localization in adults $(15+$ yrs). Note: three individuals have two different types of dental caries on a single tooth.

\begin{tabular}{cllcccccccccc}
\hline Type & \multicolumn{1}{c}{ Localization } & & I1 & I2 & C & Pm3 & Pm4 & M1 & M2 & M3 & all & \% \\
\hline crown & occlusal surface (O) & & 1 & 0 & 0 & 1 & 0 & 1 & 2 & 4 & 9 & 9.8 \\
& smooth surface caries & $(\mathrm{M}, \mathrm{D})$ & 1 & 3 & 6 & 3 & 7 & 2 & 2 & 2 & 26 & 28.3 \\
& & $(\mathrm{~B}, \mathrm{~V})$ & 0 & 0 & 0 & 0 & 1 & 0 & 0 & 1 & 2 & 2.2 \\
\multirow{4}{*}{ cervix } & cervical caries & $(\mathrm{M}, \mathrm{D})$ & 0 & 1 & 4 & 1 & 6 & 9 & 6 & 6 & 33 & 35.9 \\
& & $(\mathrm{~B}, \mathrm{~V})$ & 0 & 1 & 1 & 0 & 0 & 0 & 3 & 7 & 12 & 13.0 \\
\multirow{3}{*}{ root } & & 0 & 0 & 1 & 0 & 2 & 5 & 2 & 0 & 10 & 10.9 \\
& root caries & & 2 & 5 & 12 & 5 & 16 & 17 & 15 & 20 & 92 & \\
\hline
\end{tabular}

highest $\% \mathrm{nC}+\% \mathrm{nCE}$ level based on caries frequency in all individuals (Figure 2).

In the series of 18 children up to 14 years old (age categories $0-6$ yrs and 7-14 yrs)), in which 111 deciduous and 202 permanent teeth were examined, not even a single case of caries on a tooth was found (Table 3). By comparison, at the cemeteries of the Neolithic period, only in one child, on the first deciduous molar, was there found dental caries (Jarošová, Dočkalová 2008), whereas the Early Medieval sample at Dolní Věstonice showed $2.9 \%$ caries in deciduous teeth and $0.3 \%$ in permanent teeth $(\%$ C) (Jarošová 2007; Jarošová et al. 2012).

\subsubsection{Cariosity with regard to type and location of caries} In the Prague-Zličín population 92 examples of caries could be detected altogether on 89 permanent teeth ( 3 teeth had 2 types of dental caries: individual no. 100 - smooth surface mesial and distal caries on tooth 15 ; individual no. 117 - root caries and smooth approximal caries on tooth 33; individual no. 165 - mesial and distal cervical caries on tooth 16). In $37(40.2 \%)$ cases it was coronal caries, in $45(48.9 \%)$ cases cervical, and in $30(10.9 \%)$ cases it was root caries. In nine cases $(9.8 \%)$ out of a total 92 findings, caries was located on the occlusal surface of a crown. This can be interpreted as the presence of moderate or low dental wear with a soft diet, from which the presence of this type of caries often results.

In $26(28.3 \%)$ cases, caries was detected on non-occlusal medial or distal coronal surfaces and in $33(35.9 \%)$ cases on medial and distal cervical surfaces. In summary, 59 cases of approximal types caries (64.1\%) could thus be detected (located at the contact area of the smooth surface and approximal enamel-cementum junction) in total, which may be connected with deteriorated oral hygiene in this series. The minor part (14) (15.2\%) was represented by cervical caries on the buccal and vestibular surfaces, which is closely related with atrophy of the alveoli due to advanced age in the examined individuals - resulting in the loss of the dental crown and persistence of the root (Table 4). This effect is usually connected with alveolitis in the form of periapical abscesses, which was not studied in this sample due to the very small number of preserved alveoli and jaws.

\subsection{Occlusal wear}

Occlusal wear could be evaluated in 75 adult individuals with a total number of 539 permanent teeth from the maxilla and mandible, with a preference for the left over the right side (i.e. missing data for dental wear from the left side were replaced with data from the right side). Several adult individuals were excluded from the analysis due to having preserved alveoli, but missing teeth. Two different methods were used while assessing dental wear: incisors, canines and premolars $(\mathrm{n}=350)$ were evaluated separately from molars $(\mathrm{n}=189)$.

The degree of dental wear in incisors, canines and premolars was evaluated after Smith (1984), whereas the degree of dental wear in molars was assessed after Scott (1979). Following from the results cited in Table 5, the highest degree of dental wear could be detected on the first upper molars in individuals over 50 years old, as expected (see Figure $3 \mathrm{~b}$ ). In the incisors, canines and premolars the results of dental wear did not provide distinctly higher values according to age categories, due to the extent of the absence of scored types of teeth (see Figure 3a).

Comparing basic statistics and calculated mean values, the molars of Neolithic LBK individuals can be held up as having the most worn teeth - these values range in the 20-35 year age category in the first molars from 22.4 to 23.2, and in LgK individuals range from 21.8 to 22.0 (Jarošová, Dočkalová 2008), while individuals from Prague-Zličín range between 19.0 and 20.0, and individuals from Dolní Věstonice range between 16.7 and 17.2 (Jarošová 2007). Values of worn first molars scored in individuals who died between 35-50 years old in the Prague-Zličín population ranged from 25.1 to 26.4; individuals from Dolní Věstonice from 23.1 to 25.0, individuals from LBK have values from 27.0 to 28.0 and individuals from $\mathrm{LgK}$ even have higher values ranging between 27.3 and 30.5 . First molars scored in individuals over 50 years old in the Prague-Zličín population ranged from 36.0 to 38.0, individuals from Dolní Věstonice from 26.8 to 31.0 , whereas individuals from LBK ranged only between 31.5 and 33.0, which can be misleading because of the low number of evaluated individuals dated to the Neolithic period. In spite of the insufficient comparative sample of individuals over 50 years old, this brief summary provides evidence of a softer diet as a result of the lower scores of dental wear in individuals of the same age in the Migration period compared to the Neolithic period. Individuals from Dolní Věstonice have lower dental wear scores in all age categories than the Prague-Zličín sample, which indicates an even softer diet in the Early Middle Ages 
Table 5. Descriptive statistics of dental wear in Prague-Zličín population in adults $(15+\mathrm{yrs}) . \mathrm{N}=$ number of individuals included; $\mathrm{n}=$ number of teeth examined.

\begin{tabular}{|c|c|c|c|c|c|c|c|c|c|c|c|c|c|c|c|c|c|}
\hline & & $\stackrel{\text { İ }}{\stackrel{\Xi}{\Xi}}$ & $\underset{\mathfrak{I}}{\stackrel{\Xi}{\Xi}}$ & 己 & 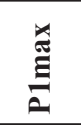 & 芯 & 离 & 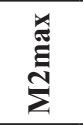 & 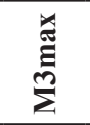 & $\stackrel{\Xi}{\stackrel{\Xi}{\Xi}}$ & $\underset{\Xi}{\stackrel{\Xi}{\Xi}}$ & 芯 & 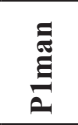 & 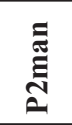 & 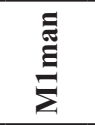 & 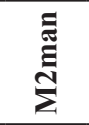 & 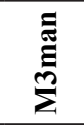 \\
\hline $\begin{array}{l}\text { rague-Zličín } \\
\mathrm{N}=75 \text { ) }\end{array}$ & $\begin{array}{l}\mathrm{n} \text { (included } \\
\text { teeth) }\end{array}$ & 28 & 25 & 36 & 30 & 38 & 31 & 35 & 30 & 31 & 33 & 44 & 41 & 44 & 33 & 3 & 27 \\
\hline \multirow[t]{7}{*}{$15-19$ yrs $(\mathrm{N}=9)$} & $\mathrm{n}$ & 6 & 4 & 6 & 7 & 7 & 6 & 8 & 6 & 5 & 6 & 6 & 6 & 6 & 6 & 5 & 3 \\
\hline & Mean & 2.83 & 2.00 & 2.33 & 2.43 & 2.29 & 11.50 & 8.88 & 6.00 & 2.20 & 2.00 & 1.67 & 1.83 & 1.83 & 13.67 & 9.20 & 5.33 \\
\hline & Median & 3.00 & 2.00 & 2.00 & 2.00 & 2.00 & 10.00 & 8.00 & 5.00 & 2.00 & 2.00 & 2.00 & 2.00 & 2.00 & 12.00 & 10.00 & 6.00 \\
\hline & nimum & 1.00 & 1.00 & 2.00 & 1.00 & 1.00 & 6.00 & 6.00 & 4.00 & 1.00 & 1.00 & 1.00 & 1.00 & 1.00 & 10.00 & 8.00 & 4.00 \\
\hline & Maximum & 4.00 & 3.00 & 3.00 & 4.00 & 4.00 & 20.00 & 14.00 & 12.00 & 3.00 & 3.00 & 2.00 & 2.00 & 2.00 & 20.00 & 10.00 & 6.00 \\
\hline & SD & 1.17 & 0.82 & .52 & .98 & 1.11 & 4.72 & 3.18 & 3.10 & 0.84 & 0.63 & 0.52 & 0.41 & 0.41 & 4.32 & 1.10 & 1.15 \\
\hline & & 1.37 & 0.67 & .27 & .95 & 1.24 & 22.30 & 10.13 & 9.60 & 0.70 & 0.40 & 0.27 & 0.17 & 0.17 & 18.67 & 1.20 & 1.33 \\
\hline \multirow[t]{7}{*}{$20-35$ yrs $(\mathrm{N}=16)$} & $\mathrm{n}$ & 3 & 4 & 6 & 3 & 5 & 5 & 6 & 6 & 3 & 3 & 3 & 3 & 5 & 2 & 4 & 2 \\
\hline & & 3.67 & 3.00 & 3.50 & .67 & 3.60 & 20.60 & 15.00 & 9.33 & & 33 & 00 & 00 & 3.20 & 20.00 & 14.50 & 15.50 \\
\hline & Median & 4.00 & 3.00 & 3.50 & 3.00 & 3.00 & 19.00 & 16.00 & 8.00 & 3.00 & 3.00 & 3.00 & 3.00 & 3.00 & 20.00 & 14.00 & 15.50 \\
\hline & & 3.00 & 2.00 & 2.00 & 2.00 & 2.00 & 17.00 & 10.00 & 6.00 & 3.00 & 3.00 & 2.00 & 2.00 & 2.00 & 20.00 & 10.00 & 10.00 \\
\hline & Maximum & 4.00 & 4.00 & 6.00 & 6.00 & 6.00 & 29.00 & 20.00 & 18.00 & 4.00 & 4.00 & 4.00 & 4.00 & 4.00 & 20.00 & 20.00 & 21.00 \\
\hline & SD & 0.58 & 0.82 & 1.52 & 2.08 & 1.82 & 4.83 & 4.34 & 4.32 & 0.58 & 0.58 & 1.00 & 1.00 & 0.84 & 0.00 & 4.43 & 7.78 \\
\hline & & 0.33 & 0.67 & 2.30 & 4.33 & 3.30 & 23.30 & 18.80 & 18.67 & & & 1.00 & 1.00 & 0.70 & 0.00 & 19.67 & 60.50 \\
\hline \multirow[t]{7}{*}{$35-50$ yrs $(\mathrm{N}=36)$} & $\mathrm{n}$ & 13 & 11 & 18 & 16 & 18 & 16 & 15 & 12 & 15 & 18 & 25 & 23 & 24 & 16 & 17 & 16 \\
\hline & Mean & 5.31 & 5.18 & 4.94 & 5.31 & 4.94 & 25.13 & 20.53 & 13.17 & 5.00 & 4.89 & 4.80 & 4.52 & 4.46 & 26.44 & 23.53 & 20.06 \\
\hline & an & 5.00 & 5.00 & 5.00 & 5.00 & 5.00 & 24.00 & 19.00 & 12.00 & 5.00 & 5.00 & 5.00 & 4.00 & 4.00 & 26.50 & & 18.00 \\
\hline & & 4.00 & 4.00 & 3.00 & 3.00 & 3.00 & 16.00 & 14.00 & 8.00 & 3.00 & 3.00 & 2.00 & 2.00 & 2.00 & 20.00 & 14.00 & 10.00 \\
\hline & & & & & & & & & 26.00 & & & 7.00 & & 6.00 & 40.00 & & .00 \\
\hline & $\mathrm{SD}$ & 1.03 & 1.08 & 1.21 & 1.40 & 1.35 & 6.28 & 4.98 & 4.86 & 1.07 & 1.13 & 1.08 & 1.12 & 0.93 & 5.57 & 7.12 & 7.78 \\
\hline & ariance & 1.06 & 1.16 & 1.47 & 1.96 & 1.82 & 39.45 & 24.84 & 23.61 & 1.14 & 1.28 & 1.17 & 1.26 & 0.87 & 31.06 & 50.64 & 60.60 \\
\hline \multirow[t]{7}{*}{$50+$ yrs $(\mathrm{N}=14)$} & 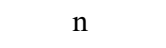 & 6 & 6 & 6 & 4 & 8 & 4 & 6 & 6 & 8 & 6 & 10 & 9 & 9 & 9 & 7 & 6 \\
\hline & ean & 5.00 & 5.00 & 4.67 & 5.75 & 5.38 & 35.25 & 27.00 & 20.83 & 5.88 & 5.67 & 5.00 & 5.00 & 5.33 & 31.56 & 24.57 & 26.83 \\
\hline & & & & & 6.00 & 5.50 & 35 & & & & & 5.00 & 5.00 & 6.00 & & & 27.50 \\
\hline & Minimum & 4.00 & 3.00 & 3.00 & 4.00 & 3.00 & 32.00 & 0 & 10.00 & 3.00 & 4.00 & 4.00 & 4.00 & 4.00 & 23.00 & 20.00 & 16.00 \\
\hline & Maximum & 6.00 & 6.00 & 5.00 & 7.00 & 7.00 & 38.00 & 32.00 & 25.00 & 8.00 & 8.00 & 7.00 & 8.00 & 6.00 & 36.00 & 34.00 & 38.00 \\
\hline & & 0.63 & 1.10 & 0.82 & 1.26 & 1.19 & 2.50 & 6.75 & 5.71 & & & .94 & 1.32 & 0.87 & 3.75 & 5.35 & 8.75 \\
\hline & Variance & 0.40 & 1.20 & 0.67 & 1.58 & 1.41 & 6.25 & 45.60 & 32.57 & 2.98 & 3.47 & .89 & 1.75 & 0.75 & 14.03 & 28.62 & 76.57 \\
\hline $15-1$ & 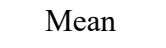 & 4.0 & 2.0 & 2.0 & 2.0 & 1.0 & 13.0 & 80 & 5.0 & & & 2 & 2.0 & 2.0 & 16.5 & 10.0 & \\
\hline $15-19$ yrs_F $(\mathrm{N}=2)$ & Mean & 3.0 & & 2.5 & 2.5 & 2.5 & 15.0 & 10.0 & 8.0 & 2. & & 2.0 & & 2.0 & 10.0 & 8.0 & 6.0 \\
\hline 15-19 yrs_M (N=3) & Mean & 2.0 & 2.0 & 2.5 & 2.7 & 2.7 & 8.0 & 9.5 & 5.0 & 2.0 & 1.5 & 1.3 & 1.5 & 1.5 & 10.5 & 9.0 & 5.0 \\
\hline $20-35$ yrs_? $(\mathrm{N}=9)$ & Mean & & 4.0 & 4.3 & & 3.0 & 18.5 & 14.0 & 7.3 & 4.0 & 4.0 & 4.0 & 4.0 & 3.7 & & 16.0 & \\
\hline $20-35$ yrs_F $(\mathrm{N}=5)$ & Mean & 3.7 & 2.5 & 2.0 & 2.5 & 3.3 & 18.5 & 14.0 & 8.0 & 3.0 & 3.0 & 2.5 & 2.5 & 2.5 & 20.0 & 14.0 & 15.5 \\
\hline 20-35 yrs_M (N=2) & Mean & & 3.0 & 4.0 & 6.0 & 5.0 & 29.0 & 20.0 & 18.0 & & & & & & & & \\
\hline 35-50yrs_? $(\mathrm{N}=9)$ & & 5.0 & 6.0 & 6.0 & 4.0 & 3.5 & 17.5 & 17.0 & 12.0 & 1.0 & 0.0 & 0.0 & 5.0 & 4.0 & 25.5 & 25.0 & 20.0 \\
\hline $35-50$ yrs_F $(\mathrm{N}=18)$ & Mean & 5.4 & 5.2 & 4.7 & 5.6 & 5.2 & 25.9 & 19.5 & 12.3 & 4.6 & 4.5 & 4.8 & 4.4 & 4.6 & 26.3 & 24.0 & 18.8 \\
\hline $35-50$ yrs_M (N=9) & Mean & 5.0 & 4.0 & 5.0 & 5.3 & 6.0 & 28.0 & 25.3 & 18.0 & 5.5 & 5.0 & 4.4 & 4.6 & 4.3 & 27.0 & 22.3 & 22.6 \\
\hline $50+$ yrs_? $(\mathrm{N}=4)$ & Mean & & & 5.0 & & 4.0 & & & 19.0 & 6.0 & & 5.5 & 5.0 & & 32.0 & & \\
\hline $50+$ yrs_F $(\mathrm{N}=5)$ & Mean & 4.8 & 4.5 & 4.0 & 5.0 & 5.3 & 27.7 & 24.8 & 24.3 & 5.0 & 1.0 & 4.2 & 4.0 & 5.0 & 30.0 & 23.4 & 32.5 \\
\hline $50+$ yrs_M $(\mathrm{N}=5)$ & Mean & 4.5 & 4.7 & 4.0 & 5.0 & 5.3 & 34.0 & 23.7 & 16.5 & 5.8 & 5.7 & 5.0 & 5.5 & 5.0 & 29.3 & 21.7 & 24.0 \\
\hline
\end{tabular}

compared to the Migration period (Figures 4 and 5).

In the Prague-Zličín population, the degree of dental wear was examined in all investigated tooth types separately for males and females. Even though males often showed a higher wear than in females (see Table 5), a nonparametric MannWhitney test did not confirm any statistically-significant difference between the wear in males and females.

\subsection{Dental enamel hypoplasia (DEH)}

Performing a complete assessment of dental enamel hypoplasia on at least one examined tooth (central or lateral incisors and canines), the following was evaluated: 1. the presence or absence of dental enamel hypoplasia (DEH); 2. acute (A DEH) and chronic (CH DEH) stressors; and 3. the type of hypoplastic defect (Table 7). The prevalence of 
Figure 3. Mean values of dental wear of (a) incisors, canines and premolars and (b) molars in Prague-Zličín population. For data source, see Table 5.
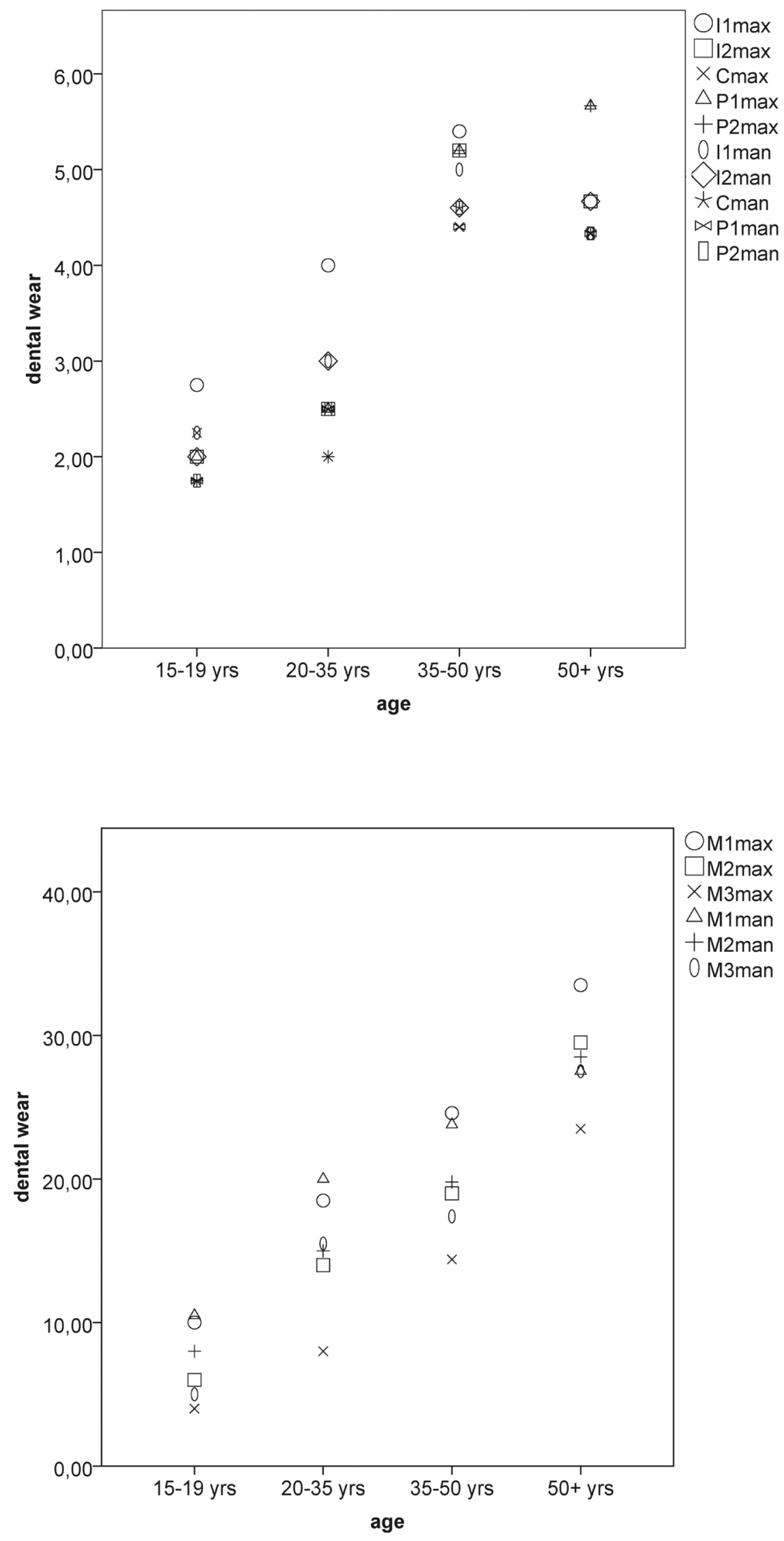


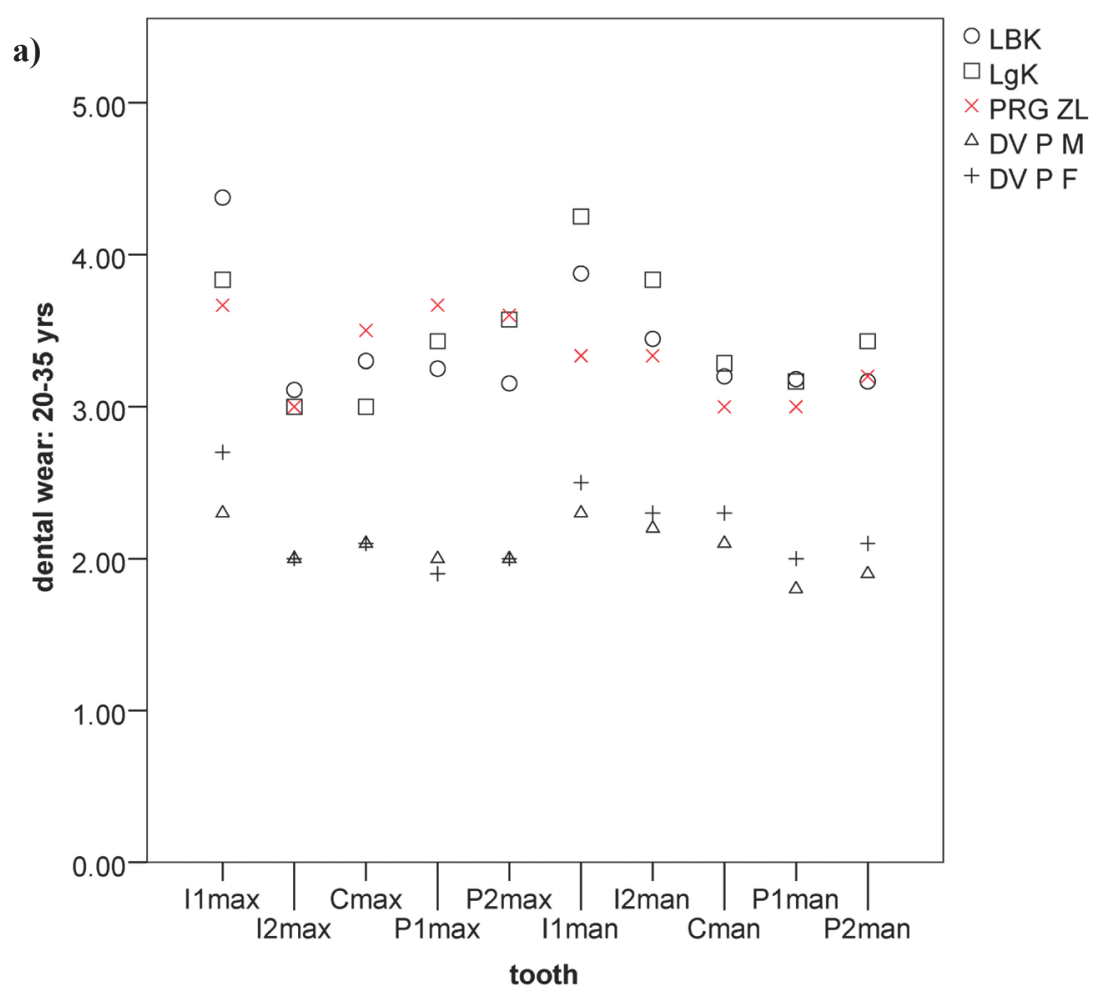

Figure 4. Mean values of dental wear of incisors, canines and premolars in the Neolithic LBK, LgK samples, and Early Medieval population from Dolní Věstonice - Na Pískách (DV P M = males; DV P $\mathrm{F}=$ females) compared to Prague-Zličín population (PRG ZL) at age (a) 20-35 years and (b) 35-50 years. For data source, see Table 5; Jarošová 2007 and Jarošová, Dočkalová 2008.

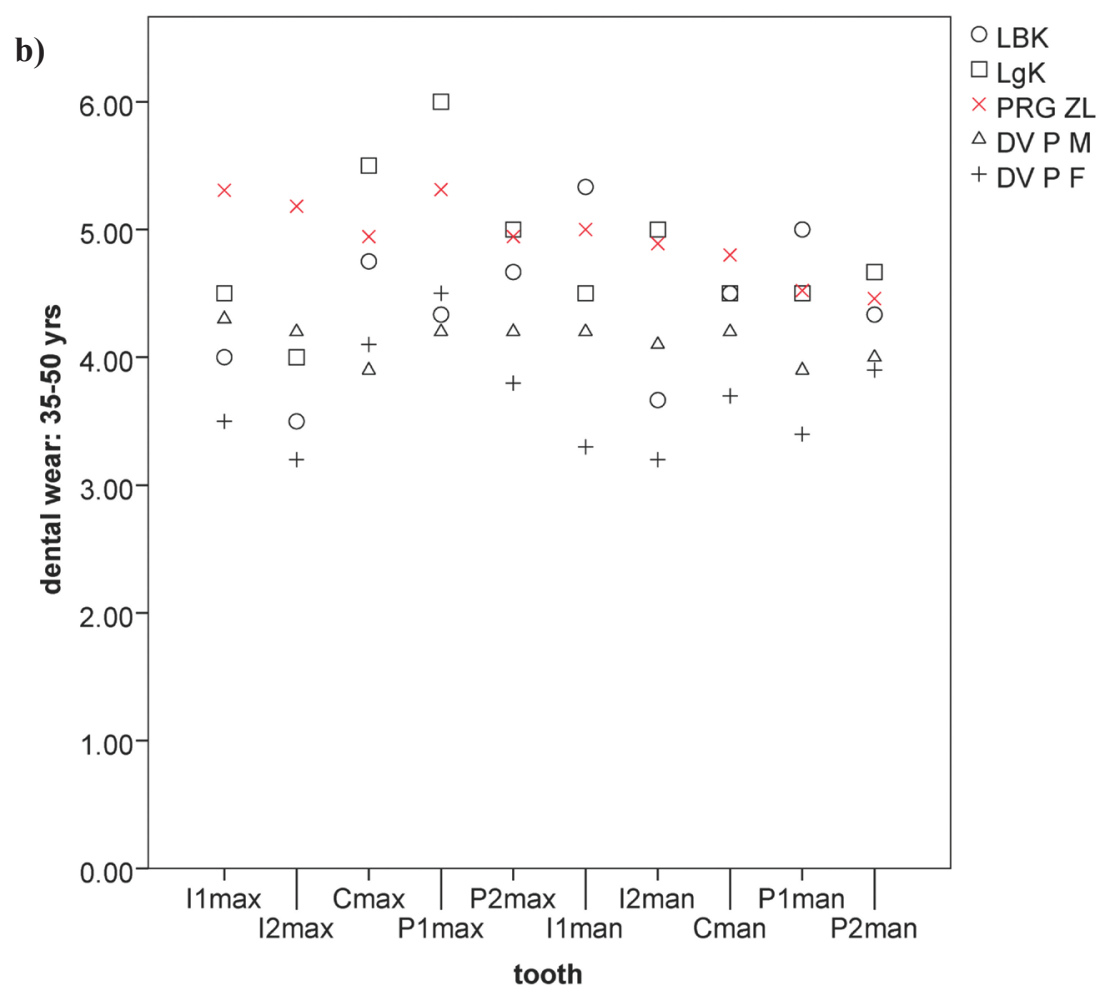

dental enamel hypoplasia was examined on 203 teeth (i.e. on 176 permanent and 27 deciduous incisors and canines), in 59 $(60.8 \%)$ of available 97 individuals with anterior dentition present.

The prevalence of hypoplasia in particular types of deciduous and permanent teeth in the Prague-Zličín sample are given in Table 6. With regard to individuals, dental enamel hypoplasia occurred most often in males (38.5\%), whereas the lowest prevalence of DEH was shown in subadults (20.0\%). Females showed a slightly lower prevalence of DEH than males $(36.4 \%)$ in the Prague-Zličín population. In summary, every third individual from the Prague-Zličín population was affected by some form of environmental or nutritional stressor during their childhood (32.2\%). 
Figure 5. Mean values of dental wear of molars in the Neolithic LBK, LgK samples, and Early Medieval population from Dolní Věstonice - Na Pískách (DV P M = males; DV P F $=$ females) compared to PragueZličín population (PRG ZL) at age (a) 20-35 years and (b) 35-50 years. For data source see Table 5, Jarošová 2007 and Jarošová, Dočkalová 2008.
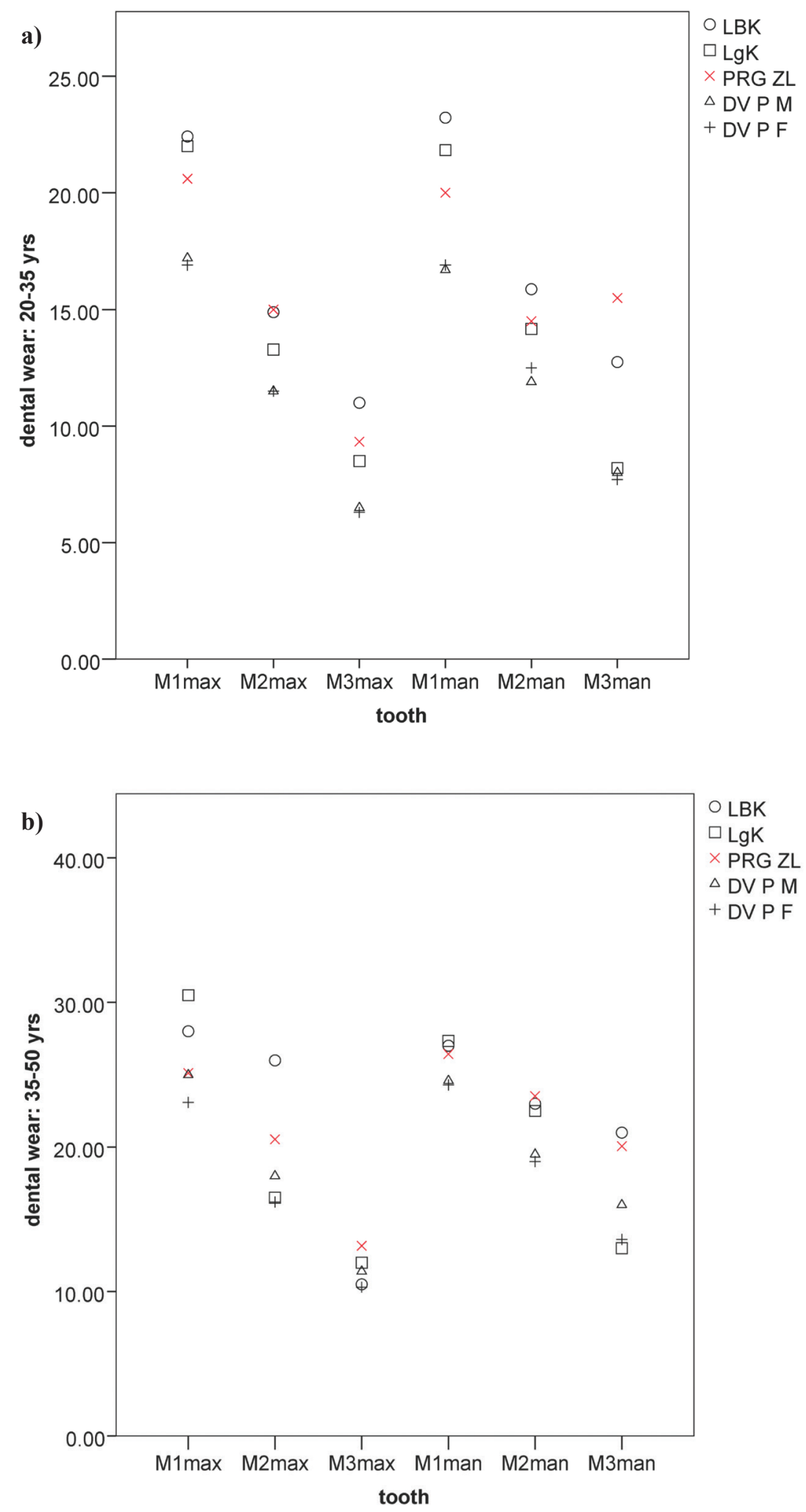

\subsubsection{Dental enamel hypoplasia with regard to teeth}

Out of a total of 176 examined permanent teeth (in 59 individuals with complete or incomplete dentition) 40 (22.7\%) showed at least one hypoplastic defect. Among the defects detected, acute stressors (97.5\%) predominated over events of a chronic character (2.5\%). Hypoplasia was mostly detected on the upper central incisors (41.2\%), and to a lesser degree on the upper canines $(25.8 \%)$ and lower canines $(24.3 \%)$. Lateral upper incisors showed a similar prevalence of DEH as the lower central incisors (upper I2 $16.0 \%$ and lower I1 $13.0 \%$ ). The lowest occurrence of DEH was recorded on the lower I2 (7.7\%) (see Table 7, Figure 6).

None of the total number of 27 examined deciduous teeth showed displays of dental enamel hypoplasia, a fact which 
Table 6. Prevalence of individuals displaying dental enamel hypoplasia (acute and chronic type).

\begin{tabular}{lccccccc}
\hline & $\begin{array}{c}\text { DEH } \\
\text { presence }\end{array}$ & $\begin{array}{c}\text { \% DEH } \\
\text { presence }\end{array}$ & $\begin{array}{c}\text { Individuals } \\
\text { analysed }\end{array}$ & $\begin{array}{c}\text { Acute DEH: } \\
\text { lines/pits }\end{array}$ & $\begin{array}{c}\text { Chronic } \\
\text { DEH }\end{array}$ & $\begin{array}{c}\text { Both acute and } \\
\text { chronic DEH }\end{array}$ & $\begin{array}{c}\text { DEH } \\
\text { absence }\end{array}$ \\
\hline subadults (0-14 yrs) & 3 & 20.0 & 15 & 3 & 0 & 0 & 12 \\
Males (15+ yrs) & 5 & 38.5 & 13 & 4 & 1 & 0 & 8 \\
Females (15+ yrs) & 8 & 36.4 & 22 & 8 & 0 & 0 & 14 \\
Ambiguous (15+ yrs) & 3 & 33.3 & 9 & 3 & 0 & 0 & 6 \\
Number of examined individuals (N) & 19 & 32.2 & 59 & 18 & 1 & 0 & 40 \\
\hline
\end{tabular}

Table 7. Prevalence of deciduous and permanent teeth displaying dental enamel hypoplasia (acute and chronic type).

\begin{tabular}{|c|c|c|c|c|c|c|c|}
\hline & \multicolumn{2}{|c|}{ Deciduous teeth } & \multicolumn{5}{|c|}{ Permanent teeth } \\
\hline & DEH presence & DEH absence & DEH presence & Teeth analysed & $\begin{array}{c}\text { Acute DEH: } \\
\text { lines/pits }\end{array}$ & Chronic DEH & DEH absence \\
\hline \multicolumn{8}{|c|}{ subadults (0-14 yrs) } \\
\hline $\operatorname{maxI1}$ & 0 & 4 & 3 & 10 & 3 & 0 & 7 \\
\hline $\max I 2$ & 0 & 4 & 2 & 11 & 2 & 0 & 9 \\
\hline $\operatorname{maxC}$ & 0 & 6 & 2 & 8 & 2 & 0 & 6 \\
\hline $\operatorname{manI1}$ & 0 & 4 & 1 & 6 & 1 & 0 & 5 \\
\hline $\operatorname{manI} 2$ & 0 & 4 & 0 & 5 & 0 & 0 & 5 \\
\hline $\operatorname{manC}$ & 0 & 5 & 1 & 5 & 1 & 0 & 4 \\
\hline permanent teeth & & & 9 & 45 & 9 & 0 & 36 \\
\hline deciduous teeth & 0 & 27 & & & & & \\
\hline \multicolumn{8}{|l|}{ adults (15+ yrs) } \\
\hline$\overline{\max I 1}$ & & & 11 & 24 & 11 & 0 & 13 \\
\hline $\max 12$ & & & 2 & 14 & 2 & 0 & 12 \\
\hline $\operatorname{maxC}$ & & & 6 & 23 & 6 & 0 & 17 \\
\hline $\operatorname{man} I 1$ & & & 2 & 17 & 2 & 0 & 15 \\
\hline $\operatorname{man} I 2$ & & & 2 & 21 & 2 & 0 & 19 \\
\hline $\operatorname{manC}$ & & & 8 & 32 & 7 & 1 & 24 \\
\hline permanent teeth & & & 31 & 131 & 30 & 1 & 100 \\
\hline
\end{tabular}

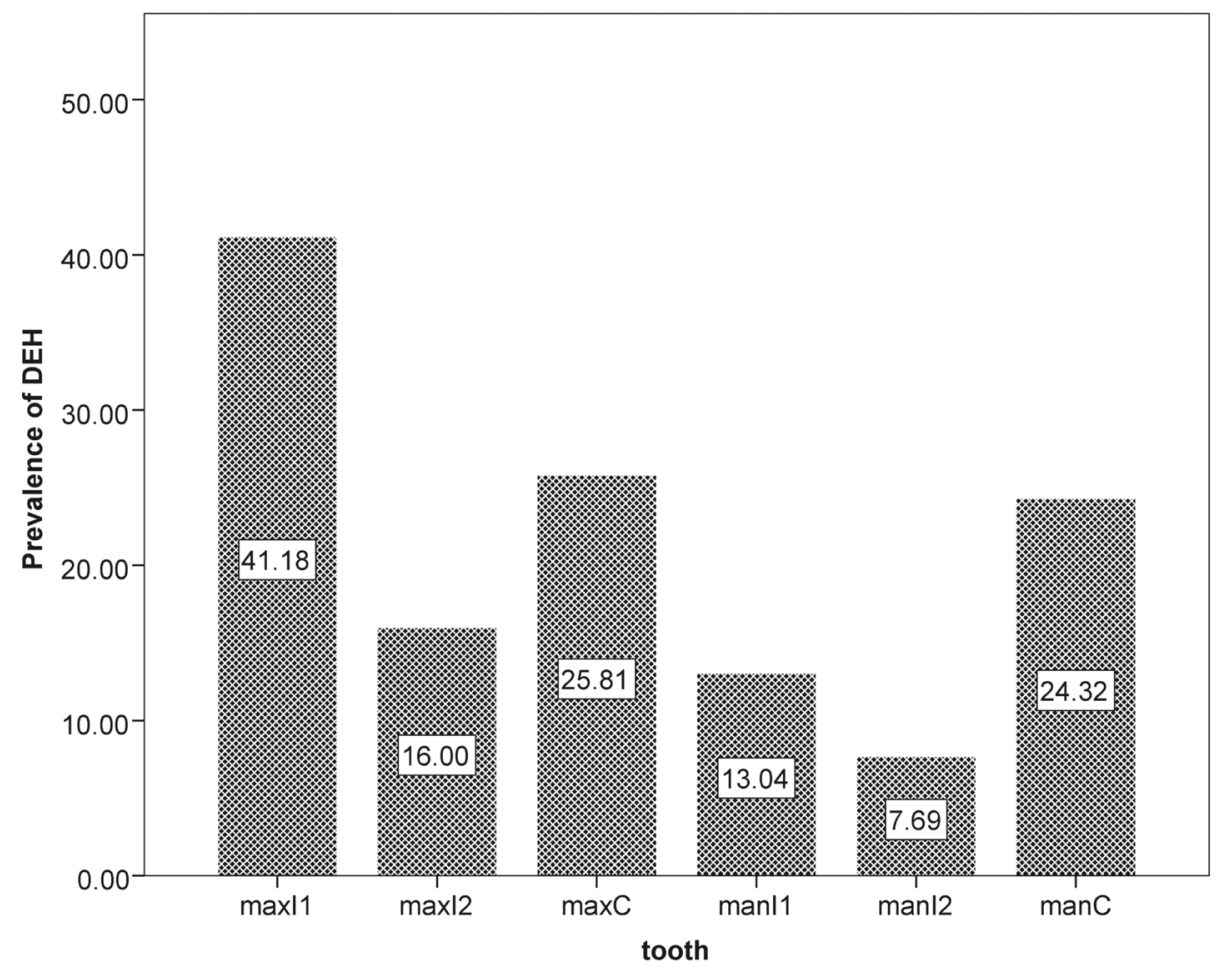

Figure 6. Prevalence of dental enamel hypoplasia (DEH) by tooth type in PragueZličín population. Data for permanent teeth (\%) are combined together for the subadult and adult samples. 


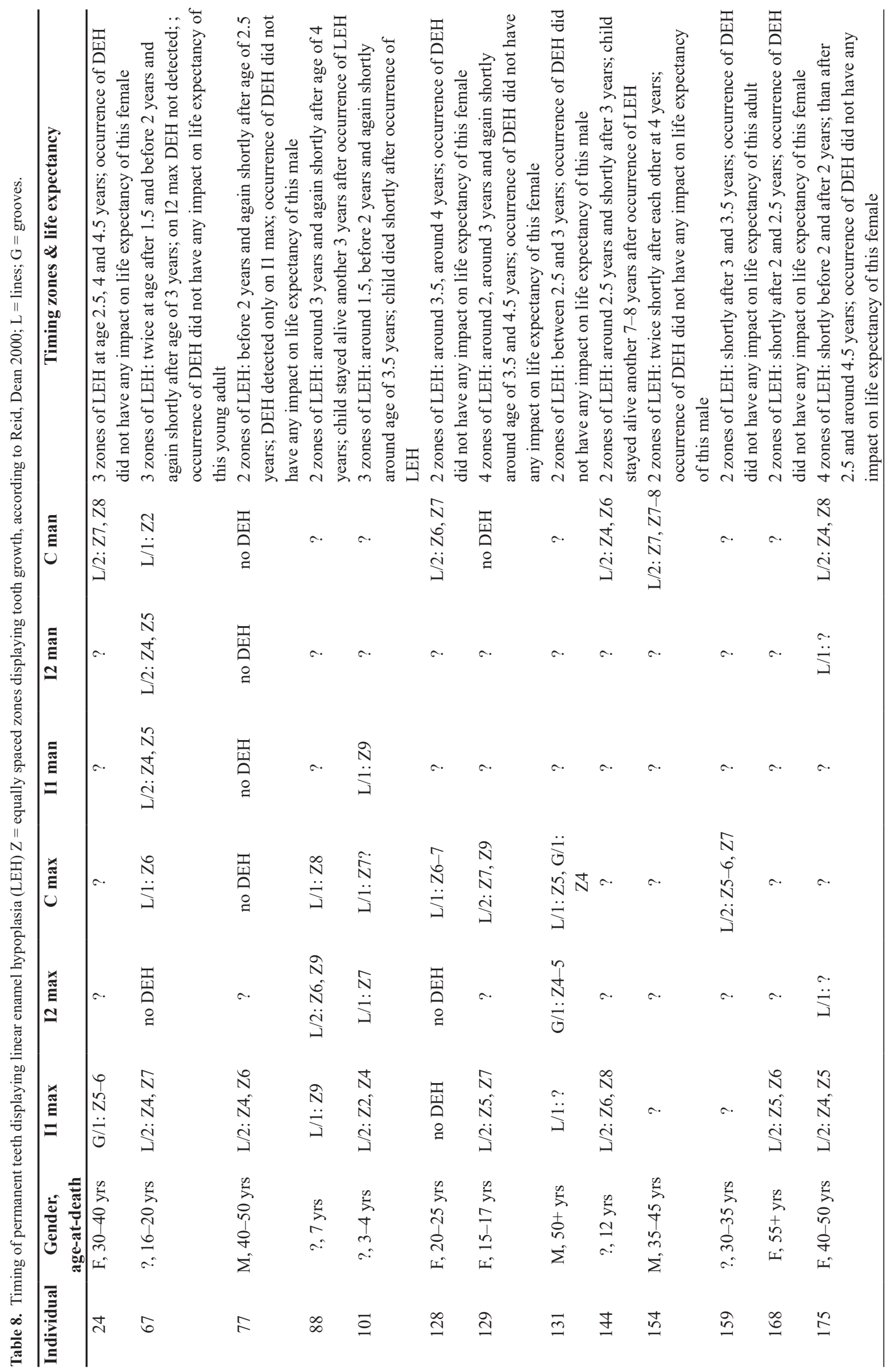



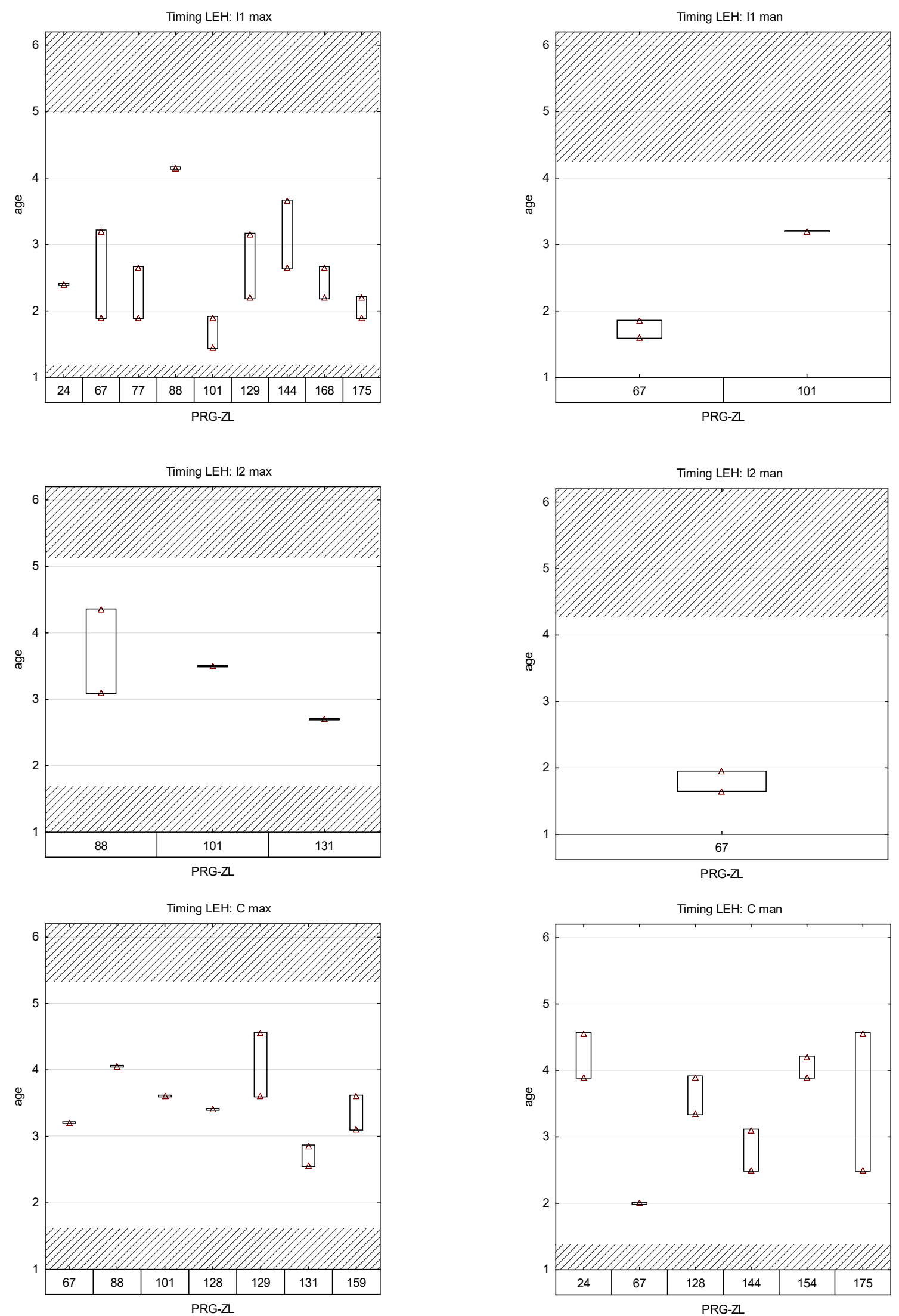

Figure 7. Timing of anterior permanent teeth displaying linear enamel hypoplasia (LEH) according to tooth type and age of occurrence in the Prague-Zličín population. Hatching indicates a zone where LEH cannot be observed either because mineralization of the tooth had not yet begun or it had already been terminated. For teeth mineralization intervals, see Reid, Dean 2000; for data source, see Table 8. 
corresponds to the occurrence of DEH in deciduous teeth in a series from Northeast Hungary (Ubelaker et al. 2006) or the Moravian Neolithic settlements (Jarošová, Dočkalová 2008). The occurrence of hypoplastic defects in the Early Medieval population from Dolní Věstonice - Na Pískách was also close to zero (Jarošová 2007; Jarošová et al. 2012).

Regarding the prevalence of DEH in other periods, the population from Prague-Zličín has high values (32.2\%) in contrast to the individuals of Neolithic settlements, who showed a very low prevalence of hypoplastic defects (14.5\%; LnK=13.5\%, LgK=18.8\%) (Jarošová, Dočkalová 2008). In the Early Medieval individuals from Dolní Věstonice - Na Pískách \%DEH was 33.0 (Jarošová 2007; Jarošová et al. 2012), which corresponds with the results obtained for the Prague-Zličín population. Considering the occurrence of DEH on incisors and canines, hypoplasia prevalence from Dolní Věstonice - Na Pískách was 34.8\%, which is four times higher than that found in the inhabitants of Moravian Neolithic settlements (8.2\%) (Jarošová, Dočkalová 2008; Jarošová 2007). Comparing the three samples studied, the lowest DEH occurrence was detected in Neolithic individuals, followed by the results from Early Medieval individuals from Dolní Věstonice - Na Pískách and individuals from Prague-Zličín, who have been affected by non-specific stressors equally often.

\subsubsection{Timing of linear enamel hypoplasia with regard to tooth growth}

The timing of linear hypoplasia on anterior teeth with regard to their tooth growth was assessed in 44 teeth of 13 individuals. Detailed case data of each individual displaying LEH on their anterior teeth are described in Table 8 and depicted in Figures 7 and 8. Complete dentition for studying LEH occurrence was present only in individual 67; all other individuals had incomplete anterior dentition including upper and lower incisors and canines. In spite of this, we can observe a full biological variability of LEH prevalence within the studied sample of 13 individuals: individuals with consistent LEH timing zones across all present anterior teeth (e.g. individual $67,131,144)$; individuals with presence of LEH only on one tooth with absence on other teeth (e.g. individual 77); or individuals displaying different time zones on different anterior teeth, even their growth covering zones of the same age (e.g. individual 24, 129, 175). A detailed overview of LEH occurrence according to each studied tooth type indicates that LEH was most often present on

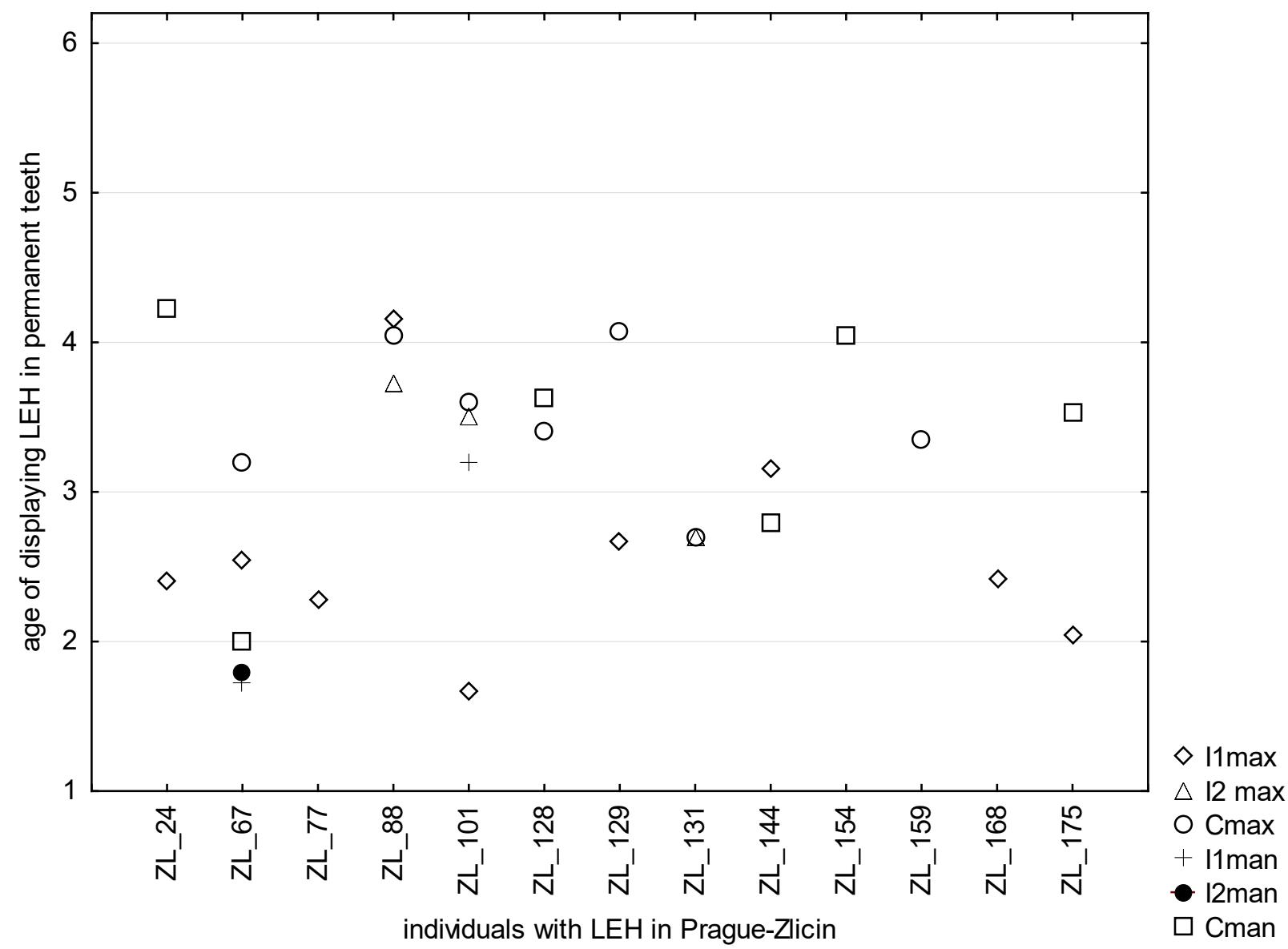

Figure 8. Age at which linear enamel hypoplasia (LEH) displayed in anterior permanent teeth of 13 examined individuals from the Prague-Zličín population. For data source, see Table 8 . 
I1 max between 1.5 and 3.5 years, even the appearance of the completion of zones of enamel formation varying between 1.1 to 5.0 years. The occurrence of LEH on $\mathrm{C}$ max and $\mathrm{C}$ man was frequently between 2.5 and 4.5 years (see Figure 7), ranging from 1.7 to 5.3 years on $\mathrm{C}$ max and 1.5 to 6.2 years on $\mathrm{C}$ man. In some cases, the presence of lines across different zones within the anterior teeth of a single individual (see Figure 8) could be misinterpreted due to the macroscopic assessment of each tooth; this has to be also considered as a negative factor, even with a magnifying glass being used and teeth with high dental wear being excluded from the timing of LEH analysis.

In the studied Prague-Zličín series it was possible to examine the timing of LEH in only 3 subadults. Among these 3 individuals, only child no. 101 had died shortly after the last occurrence of LEH, which cannot be considered as the main reason for death, but could be considered as one of the stressors that did not improve the child's state of health. From the demographic point of view, in the other children and in all adults the presence of LEH did not have any impact on their life expectancy.

\section{Discussion}

Only rarely is there information available from an archaeological and historical context for the reconstruction of food sources of Migration populations. Since in their food sources Migration populations were probably dependent on agrarian products for the greater part, cereals can be considered as the main source of carbohydrates/starch (polysaccharides) in their diet. Other possible sources could have been honey or fruit. Archaeobotanical analysis of the macro-remains of useful plants from the infill of graves has shown barley (Hordeum vulgare) as the dominant cereal crop, with a remarkable proportion of millet (Panicum miliaceum), at Prague-Zličín. Among other cereals, common or compact wheat (Triticum aestivum/compactum) and oat (Avena sp.) were found. The remains of rye (cf. Secale cereale) and spelt wheat (Triticum cf. spelta) were found inside coffins, while the remains of emmer wheat (cf. Triticum dicoccum) were found in samples from grave infill and shafts. Seeds of lentil (Lens culinaris) and pea (Pisum sativum, Vicia/Pisum) were also discovered (see Šálková et al. 2016-this IANSA issue). This is in accordance with other macro-remain research performed at other Czech settlement features, which have confirmed T. aestivum/turgidum, Hordeum and T. dicoccum as the most important cereals in the rare finds pertaining to the Migration Period (Dreslerová, Kočár 2013). As confirmed by osteoarchaeological analysis at Prague-Zličín, the main source of meat was domestic animals (cattle $-21.0 \%$, pig $-16.5 \%$, sheep/goat $-0.3 \%$ ), supplemented by the hunting of wild fauna (Nohálová et al. 2016 - this IANSA issue; note: $56.4 \%$ of all animal bones were identified as rodents). Information on food sources from the Migration period is quite rare in historical texts. Jordanes in his description of the conflict between the Goths and Sueves, mentions that it was started by a raid on Dalmatia for the purpose of cattle robbery. We can infer from this report of Jordanes (Getica, 273) that cattle played a special role in the economy (and thus probably the nutrition) of the Barbarians. Unfortunately there are only rare osteological data available from other archeological sites, providing only an incomplete picture of the composition of meat sources in the Czech Republic at that time. Regarding the analysis of buccal dental microwear, it was shown that the ratio of meat consumed by individuals at Prague-Zličín was higher than their cereal intake (see Jarošová et al. 2016 - this IANSA issue). As fruit and honey are impossible to directly detect as sources of carbohydrates/starch (polysaccharides) in the diet of Prague-Zličín individuals, and we have only clues for their consumption of cereal, we can only conclude that cereal intake - together with other carbohydrates sources - resulted in an increase of dental caries for the PragueZličín population. The emergence of caries depended on two cardinal factors: the $\mathrm{pH}$ of dental plaque and the composition of carbohydrates contained in food consumed. If the acidity of dental plaque exceeded the threshold value, then a disturbance to the dental enamel would occur and the emergence of caries would follow (Hillson 1979, 149-150). In the Prague-Zličín population caries intensity (I-CE) was detected in $21.0 \%$ of teeth; among the Prague-Zličín individuals more than half were affected by caries or antemortem loss ( $\mathrm{F}-\mathrm{CE}=59.5)$. In the populations from Moravian Neolithic settlements, caries - and its impact in the form of intravital losses - were detected in $10.3 \%$ of teeth and in $38.8 \%$ of individuals, a relatively low value compared to the later Medieval population from Dolní Věstonice, which showed a caries intensity of 15.3 and a caries frequency of 59.6, or the Prague-Zličín population, which presented the highest values among all comparative samples.

The food consumed in the Neolithic period must have been of a much denser consistency than today. Due to an extremely increased enamel wear, dental caries occurred less often on the occlusal surface than on the other dental surfaces. This pattern is opposite to that of the Prague-Zličín population - occlusal dental wear is low and the frequency of occlusal dental caries relatively high, which suggests a switch in food composition and processing between these two series.

Among children not even a single case of caries on a tooth could be detected in the Prague-Zličín population and only a single case of caries in the Neolithic samples, from which we cannot draw any solid conclusions.

The highest values of dental wear were recorded in the LBK individuals. Individuals of this oldest Neolithic period must therefore have subsisted on a highly abrasive food containing some unspecified abrasive matter, which resulted in the excessive crown wear. In the later Migration period a change in food composition or preparation must have occurred, which was reflected in their lower dental wear pattern; the lowest dental wear was recorded in the Early Medieval population in Dolní Věstonice, whose diet composition has to have been the softest among all the 


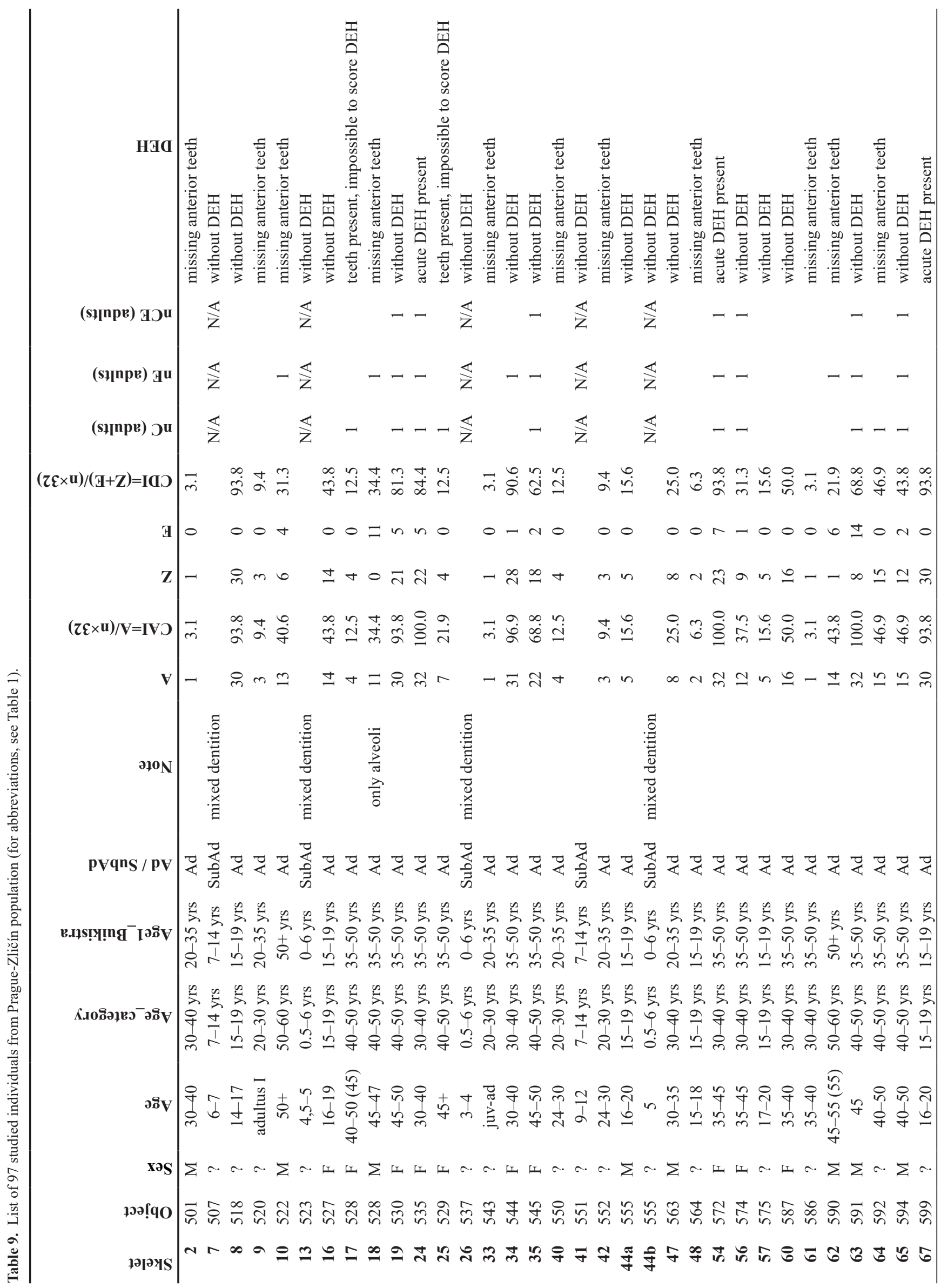




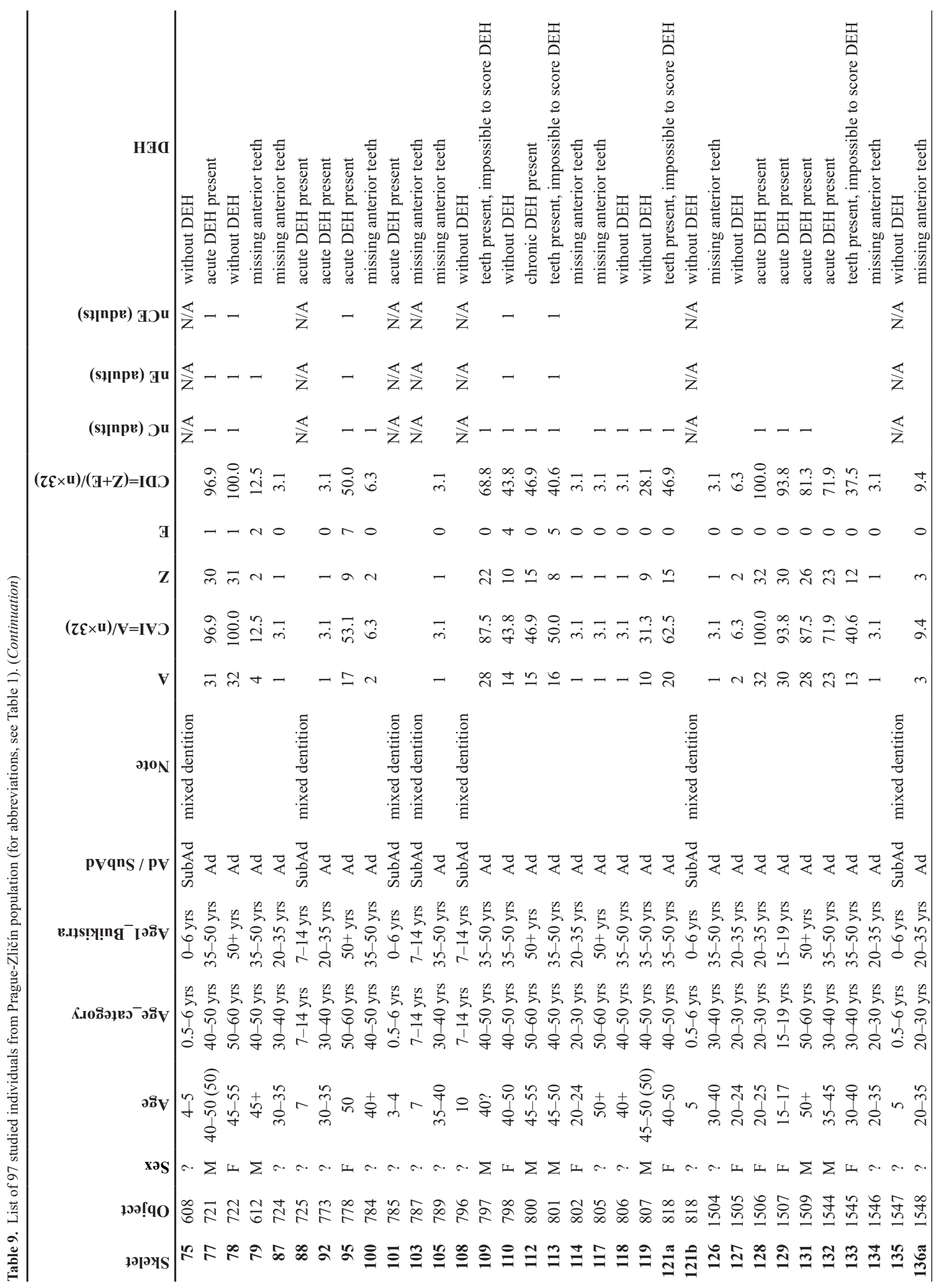




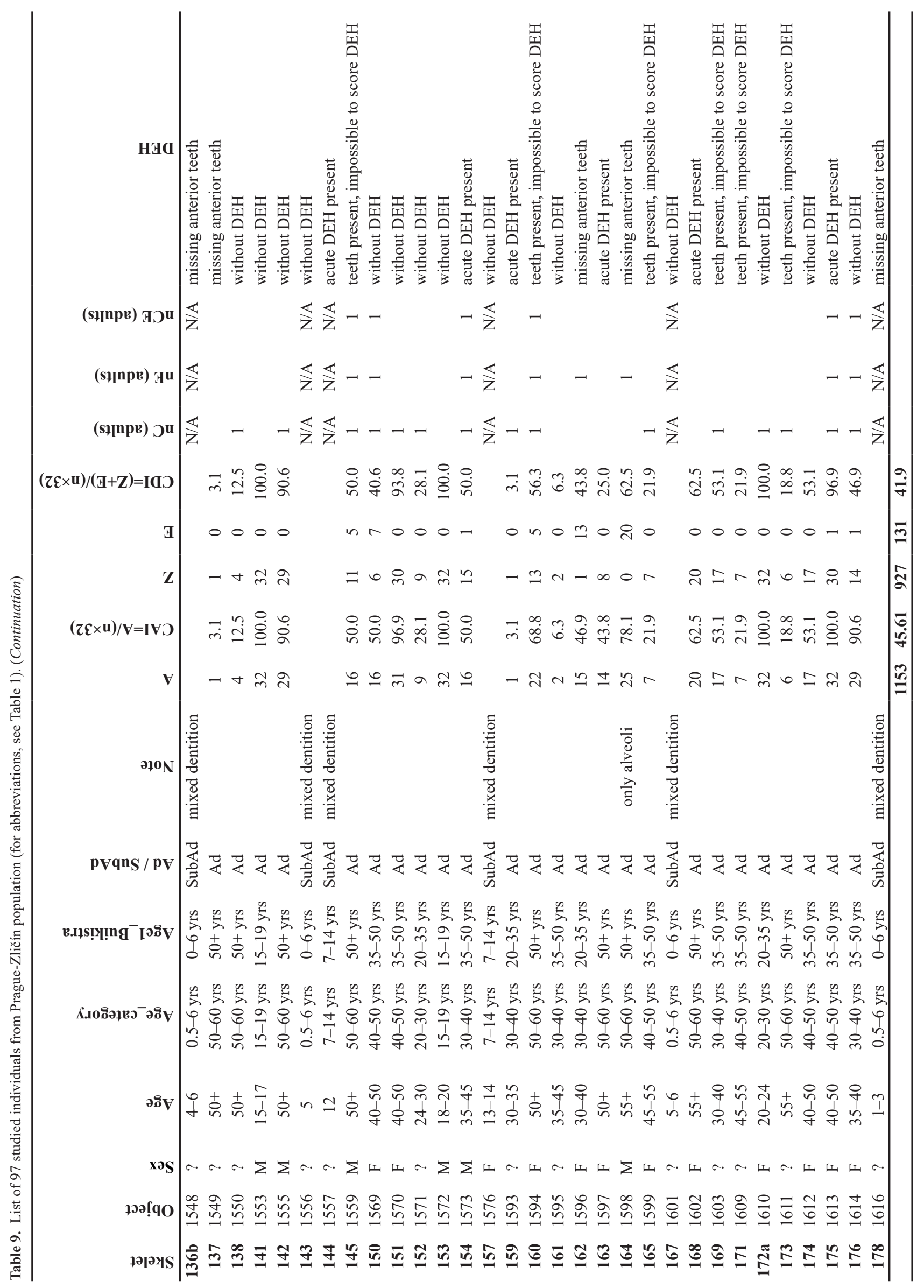


comparative series. By contrast, the highest degree of dental wear detected in the LBK period, especially on the first upper incisors, most probably is related to the use of their teeth as a tool; this was observed through occlusal microwear analysis which indicated the transversal passing of some type of flexible material over the anterior teeth in a repetitive and habitual way as in the processing of some kind of material such as sinews for bow strings, or plant fibres for cordage or basketry (see Larsen 1997, 259). In the period following the LgK culture, this custom must have gradually declined until it was abandoned completely (Jarošová, Dočkalová 2008).

In the Neolithic population from settlements, dental enamel hypoplasia was recorded by $14.5 \%$ with some deviations relating to particular time periods. The Neolithisation process can be characterized by the relatively constant impact of non-specific stressors that resulted in displays of dental enamel hypoplasia, along with the overall fitness of Neolithic populations. In other words, nutritional conditions and their state of health did not change significantly during the Neolithic period, the population's resistance/adaptation to environmental impacts in connection with socio-economic status showing a similar fitness and physical efficiency, which was also probably related to their reproductive capacity (Jarošová, Dočkalová 2008). Comparing the data from later periods, the DEH prevalence of the Prague-Zličín population was approximately the same $(32.2 \%)$ as in the Early Medieval population from Dolní Věstonice (33.0\%); it can be assumed that both studied populations did not enjoy very favourable living conditions, as proved by their abilities to cope with the insults of non-specific stressors. Such an assumption should be verified by the occurrence of other non-specific stress markers being observed on their skeletal remains, such as the incidence of Harris lines or cribra orbitalia.

\section{Conclusion}

This paper has been focused on some basic dental aspects of the Prague-Zličín population buried in Central Bohemia, its aim being to capture the changes that became inscribed in the dentition of these people during the Migration period ( $5^{\text {th }}$ century $\left.A D\right)$. With the help of such data the living conditions of this past population can be partially reconstructed and then these results can be compared with other population series from the Czech Republic. Evaluation of dental condition was performed on 18 subadult (0-14 year-old), and 79 adult individuals (15+ year-old) with a total of 1240 teeth from Prague-Zličín. These individuals of the Migration period, in comparison to the other Neolithic and Early Middle Age samples, are characterised by their high dental cariosity ( $\mathrm{I}-\mathrm{CE}=21.0$, of which 24.0 pertains to males and 21.3 to females; $\mathrm{F}-\mathrm{CE}=59.6$ ), which would most likely indicate an increased consumption of polysaccharides (starch), together with a deteriorating level of dental hygiene. The most frequent type of dental caries was found in the mesial and distal facets of the cemento- enamel junction and smooth surfaces of the crown (64.1\%), which in this population series may be connected with their deteriorated oral hygiene. The $9.8 \%$ of dental caries being located on the occlusal surface of the crown, together with their proven moderate or low dental wear, can be interpreted as the presence of a softer diet during the Migration period ( $5^{\text {th }}$ century $\left.\mathrm{AD}\right)$; dental wear analysis showed that their results reached the lower values within the comparative Neolithic, LBK and LgK populations. The sample dated to the Early Middle Ages had the lowest dental wear scores, which can be interpreted, within these comparative series, as their consuming the softest diet in that period $\left(9-11^{\text {th }}\right.$ century AD).

In the Moravian Neolithic population, dental enamel hypoplasia (DEH) was recorded in $14.5 \%$ of individuals; in the LBK period in $13.5 \%$, and at the end of the Neolithic (LgK) already in $18.8 \%$ of individuals. In the Migration period, DEH was present at a higher frequency (32.2\%), approximately the same as the Early Middle Ages series (33.0\%). This increase in the prevalence of DEH in both the Prague-Zličín and Early Medieval population may be connected with the increased extent of non-specific stressors (i.e. indicators of metabolic and nutritional disruptions). By contrast, the Neolithic people enjoyed very favourable living conditions, as proved by the ability to cope with the later insults of non-specific stressors within these populations, according to the recorded low prevalence of dental enamel hypoplasia and overall very good state of dental health. This could also be caused by there being a different food composition during the Neolithic and later periods, and its impact on those past populations making a measurable difference.

In the Prague-Zličín Migration population, all of the records of past stressors in childhood have short-term acute forms in the types of lines or grooves. Only one single case provided evidence of a chronic form of DEH. The timing of linear enamel hypoplasia (LEH) studied in 13 individuals provided an assessment of the occurrence and frequency of the individual's age when LEH formed.

\section{Acknowledgement}

This research was supported by the Czech Science Foundation; grant number P405/13-18955S. The author would like to thank the very helpful comments of two anonymous peer-reviewers.

\section{References}

ANDRIK, P., MÜNCNEROVÁ, Z. 1961: K výskytu zubného kazu v predhistorických dobách. Československá stomatologie 61/5, 347-353. AUFDERHEIDE, A. C., RODRÍGUEZ-MARTÍN, C. 1998: The Cambridge encyclopedia of human paleopathology. Cambridge University Press, New York.

BUIKSTRA, J. E., UBELAKER, D. (Eds.): 1994: Standards for Data Collection from Human Skeletal Remains. Missouri Archaeological Society. Proceedings of a Seminar at the Field Museum of Natural 
History. Arkansas Archeological Survey Research Seminar Series No. 44, Arkansas.

CASElitZ, P. 1998: Caries - Ancient Plague of Humankind. In: Alt, K. W., Rösing, F. W., Teschler-Nicola, M. (1998): Dental anthropology. Fundamentals, Limits, and Prospects. Springer, Wien - New York, 203226.

CORRUCCINI, R. S., HANDLER, J. S., JAKOBI, K. P. 1985: Chronological distribution of enamel hypoplasias and weaning in Caribbean slave population. Human Biology 57, 699-711.

DRESLEROVÁ, D., KOČÁR, P. 2013: Trends in cereal cultivation in the Czech Republic from the Neolithic to the Migration period (5500 B.C.A.D. 580). Vegetation History and Archaeobotany 22/3, 257-268.

EL-NAJJAR, M. Y., DeSANTI, M. V., OZEBEK, L. 1978: Prevalence and Possible Etiology of Dental Enamel Hypoplasia. American Journal of Physical Anthropology 48, 185-192.

ENSOR, B. E., IRISH, J. D. 1995: Hypoplastic area Method for Analyzing Dental Enamel Hypoplasia. American Journal of Physical Anthropology 98, 507-517.

FRAYER, D. 2004: Dental remains from Krškany (Slovakia) and Vedrovice (Czech Republic). Anthropologie 42/1, 71-103.

GOODMAN, A. H. 1993: On the interpretation of health from skeletal remains. Current Anthropology 34, 281-288.

GOODMAN, A. H. 1998: Variation in time of tooth formation and eruption. In: Ulijaszek, S. J., Johnston, F. E., Preece, M. A. (Eds.): The Cambridge Encyclopedia of Human Growth and Development. Cambridge University Press, Cambridge.

GOODMAN, A. H., ARMELAGOS, G. J. 1985: Factors Affecting the Distribution of Enamel Hypoplasias within the Human Permanent Dentition. American Journal of Physical Anthropology 68, 479-493.

GOODMAN, A. H., ARMELAGOS, G. J. 1989: Infant and childhood morbidity and mortality risks in archaeological populations. World Archaeology 21, 225-243.

GOODMAN, A. H., ROSE, J. C. 1990:Assessment of Systemic Physiological Preturbations from Dental Enamel Hypoplasias and Associated Histological Structures.Yearbook of Physical Anthropology 33, 59-110.

GOODMAN, A. H., PELTO, G. H., ALLEN, L. H., CHAVEZ, A. 1992: Socioeconomic and anthropometric correlates of linear enamel hypoplasia in children from Solis, Mexico. Journal of Paleopathology Monograph Publiblication 2, 373-380.

HANÁKOVÁ, H., STLOUKAL, M. 1966: Staroslovanské pohřebiště v Josefově. Antropologický rozbor. Rozpravy Československé akademie věd, řada společenských věd 76, Praha.

HILLSON, S. 1979: Diet and dental disease. World archaeology 11/2, 147-162.

HODGES, D. C., WILKINSON, R. G. 1990: Effect of tooth size on the ageing and chronological distribution of enamel hypoplastic defects. American Journal of Human Biology 2, 553-560.

HORÁKOVÁ, M., JAROŠOVÁ, I., VÁVRA, J., JIŘÍK, J., KUCHǍ̌ÍK, M. 2014: Food strategies during the Migration period: A study of the Prague-Zlicin population. In: The Dolni Věstonice Studies, vol. 20 Mikulov Anthropology Meeting 2014, 159-162.

HORÁKOVÁ, M., JAROŠOVÁ, I., 2015: Lidé z pohřebiště v PrazeZličíně pohledem fyzického antropologa. In: Jiř́k, J., Vávra, J., Šmolíková, M., Kuchařík, M. et al. (Eds.): Hroby barbarů v Praze Zličíně. Svět živých a mrtvých doby stěhování národi̊. Muzeum hlavního města Prahy, Praha, 221-231.

HRNČÍŘOVÁ, M., JAROŠOVÁ, I. 2007: Slovanské obyvatelstvo z Dolních Věstonic: komparační paleodemografická studie raně středověkých pohřebišt'. (The Slavic population of Dolní Věstonice: A comparative palaeodemographic study of the Early Medieval cemeteries) Archeologické rozhledy 59/1, 29-52.

JAROŠOVÁ, I. 2007: Paleonutriční studie z odontologických aspektů u staroslovanského obyvatelstva z Dolních Věstonic. MS. Ph.D. Thesis. Deposited: Library of Faculty of Science, Masaryk University, Brno.

JAROŠOVÁ, I., DOČKALOVÁ, M. 2008: Dental remains from the Neolithic settlements in Moravia, Czech Republic. Anthropologie 46/1, 77-101.

JAROŠOVÁ, I., FOJTOVÁ, M., TVRDÝ, Z. (Eds.) 2012: Antropologická analýza raně stredověké populace z Dolnich Věstonic - Na Pískách (Anthropological Analysis of the Early Medieval Population from Dolní Věstonice - Na Piskách). Moravské zemské muzeum, Brno.
ANTHROPOS, Studies in Anthropology, Palaeoethnology, Palaeontology and Quaternary Geology, Vol. 34, N.S. 26.

JAROŠOVÁ, I., VÁVRA, J., JIŘIIK, J., HORÁKOVÁ, M. 2016: Buccal dental microwear of a Barbarian population from Prague-Zličín - a study of Migration Period in Czech Republic. Interdisciplinaria archaeologica - Natural Sciences in Archaeology VII/1/2016, 55-70.

JIŘÍK, J., VÁVRA, J., ŠMOLÍKOVÁ, M., KUCHAŘÍK, M. et al. 2015: Hroby barbarů v Praze Zličině. Svět živých a mrtvých doby stěhování národi̊. Muzeum hlavního města Prahy, Praha.

JORDANES 1915: The Origin and Deeds of the Goths, The Getica, translated by C.C.Mierow (1915). Princeton University Press, Princeton \& Oxford University Press, London.

KILIÁN, J. et al. 1999: Prevence ve stomatologii. Galén, Univerzita Karlova, Praha.

LARSEN, C. S. 1997: Bioarchaeology. Interpreting behavior from the human skeleton. Cambridge University Press, Cambridge.

LILLIE, M. C. 1996: Mesolithic and Neolithic Populations of Ukraine: Indicators of Diet From Dental Pathology. Current Anthropology 37/1, 135-142.

LINGSTRÖM, P., BORRMAN, H. 1999: Distribution of Dental Caries in an Early $17^{\text {th }}$ Century Swedish Population with Special Reference to Diet. International Journal of Osteoarchaeology 9, 395-403.

LITTLETON, J. 2005: Invisible Impacts but Long-Term Consequences: Hypoplasia and Contact in Central Australia. American Journal of Physical Anthropology 126, 295-304.

LUKACS, J. R. 1992: Dental paleopathology and agricultural intensification in south Asia: New evidence from Bronze Age Harappa. American Journal of Physical Anthropology 87, 133-150.

MAIR, L. H., 1999: Understanding wear in dentistry. Compendium 20, 19-30.

MAIR, L. H., STOLARISK, T. A., VOWLES, R. W., LlOYD, C. H. 1996: Wear: Mechanisms, Manifestation and Measurement. Journal of Dentistry 24, 141-148.

MALVILLE, N. J. 1997: Enamel Hypoplasia in Ancestral Puebloan Populations From Southwestern Colorado: I. Permanent Dentition. American Journal of Physical Anthropology 102, 351-367.

MOORE, W. J., CORBETT, M. E. 1971: The Distribution of Dental Caries in Ancient British Populations 1: Anglo-Saxon period. Caries Research 5, $151-168$.

NOHÁlOVÁ, H., VÁVRA, J., KUCHAŘíK, M. 2016: Dog Burial and Animal Bone Remains from the Human Graves in Prague-Zličín. Interdisciplinaria Archaeologica - Natural Sciences in Archaeology VII/1/2016, 71-86.

OBERTOVÁ, Z. 2005: Environmental stress in the Early Mediaeval Slavic population at Borovce (Slovakia). Homo - Journal of Comparative Human Biology 55, 283-291.

REID, D. J., DEAN, M. C. 2000: Brief communication: The timing of linear hypoplasias on Human Anterior teeth. American Journal of Physical Anthropology 113, 135-139.

ŠÁlKOVÁ, T., DOHNALOVÁ, A., NOVÁK, J., HILTSCHER, T., JIŘIK, J., VÁVRA, J. 2016: Unrecognized Taphonomy as a Problem of Identification and the Scale of Contamination of Archaeobotanical Assemblages - the Example of Prague - Zličín Migration Period Burial Ground. Interdisciplinaria Archaeologica - Natural Sciences in Archaeology VII/1/2016, 87-110.

SANTOS, R. V., COIMBRA, C. E. A. 1999: Hardships of Contact: Enamel Hypoplasias in Tupí-Mondé Amerindians from the Brazilian Amazonia. American Journal of Physical Anthropology 109, 111-127.

SARNAT, B. G., SCHOUR, I. 1941: Enamel hypoplasia (chronologic enamel aplasia) in relation to systemic disease: A chronologic, morphologic and etiologic classification. Journal of American Dental Association 28, 1989-2000.

SAUNDERS, S. R., DEVITO, C., KARZENBERG, M. A. 1997: Dental Caries in Nineteenth Century Upper Canada. American Journal of Physical Anthropology 104, 71-87.

SCOTT, E. 1979: Dental wear scoring technique. American Journal of Physical Anthropology 51, 213-217.

SIVAPATHASUNHARAM B., RAGHU A. R. 2012: Dental caries. In: Rajendran, A. Sivapathasundharam, B. (Eds.): Shafer's Textbook of Oral Pathology. $7^{\text {th }}$ edition, Elsevier India, ebook, 419-474.

SMITH, B. H. 1984: Patterns of Molar Wear in Hunter-Gatherers and 
Agriculturists. American Journal of Physical Anthropology 63, 39-56. STLOUKAL, M. 1963: Gesundheitszustand des Gebisses bei der Population von grossmährischen Mikulčice. Anthropologie 3, 35-45.

UBELAKER, D. H., PAP, I., GRAVER, S. 2006: Morbidity and Mortality in the Neolithic of Northeastern Hungary. Anthropologie 44/3, 241-257.

VÁVRA, J., JIŘÍK, J., KUCHAŘÍK, M., KUBÁLEK, P. 2008: Výzkum pohřebiště z doby stěhování národů v Praze-Zličíně v letech 2005-2008 (Migration Period cemetery in Prague-Zličín, excavated in 2005-08). Archaeologica Pragensia 19, 211-232.

VÁVRA, J., JIŘíK, J., KUCHAŘÍK, M., JAROŠOVÁ, I., VÍŠKOVÁ, M., KUBÁLEK, P. 2012: The Migration Period burial site in Prague-Zličín,
Czech Republic. Preliminary report. Zeitschrift für Archäologie des Mittelalters 40, 1-25.

VÍŠKOVÁ, M., JAROŠOVÁ, I., JIŘíK, J., VÁVRA, J., KUCHAŘíK, M. 2012: Populace $\mathrm{z}$ doby stěhování národů $\mathrm{z}$ pohřebiště $\mathrm{v}$ Praze-Zličíně z pohledu fyzické antropologie. Acta Musei Nationalis Pragae, Series A, Historia 66/3-4, 61-70.

WOTKE, J. 2001: Patologie orofaciálni oblasti. Avicenum, Grada Publishing, Praha.

WRIGHT, L. E. 1997: Intertooth Patterns of Hypoplasia Expression: Implications for Childhood Health in the Classic Maya Collapse. American Journal of Physical Anthropology 102, 233-247. 